DONALD D. HESTER

University of Wisconsin-Madison

\title{
Innovations and Monetary Control
}

THE U.S. financial system has changed greatly in the past twenty years and will unquestionably continue to evolve in response to challenges and opportunities. In this paper I survey a number of important innovations that have occurred in an attempt to understand the forces that led to change and the consequences the innovations have for the future conduct of monetary policy. As will be seen, each of the innovations is itself a response to conditions that existed in money and capital markets on some date. Indeed, it can be claimed that each innovation was induced by monetary policy decisions that were taken before that date.

Individually and collectively the innovations probably have had an expansive effect on the economy, because it is likely that each led to a decline in the required rate of return for holding capital. ${ }^{1}$ The new financial instruments and institutions are competing successfully with assets,

Research support from a National Science Foundation grant is gratefully acknowledged. I am indebted to Andrew S. Carron and Stephen M. Goldfeld for their comments, which led to several improvements. I also want to thank the other members of the Brookings panel for a number of constructive suggestions.

1. The issue, as usual, hinges upon whether all assets in the private sector's portfolio are gross substitutes. The innovations considered in this paper have tended to nullify regulatory interferences such as reserve requirements and interest rate ceilings on deposits. In the absence of such regulatory interferences, the assumption of gross substitutability leads to the prediction in the text. See James Tobin and William C. Brainard, "Financial Intermediaries and the Effectiveness of Monetary Controls," American Economic Review, vol. 53 (May 1963, Papers and Proceedings, 1962), pp. 383-400. 
liabilities, and institutions that existed before 1960. The resulting richer mixture of saving and investing mediums is very likely to augment investment flows and reduce the inconveniences of holding physical capital. A given monetary base or stock of outside money will be associated with a larger equilibrium stock (fund) of capital.

In this analysis a monetary authority that wants to achieve a target level of economic activity probably should reduce the growth rate of monetary aggregates or increase interest rates when it perceives that innovations are occurring. However, its action might be self-defeating. There is no assurance that its objective can be achieved more than temporarily; it may just spawn another round of innovations.

A basic tenet of this paper is that monetary policy is poorly designed if it fails to take into account the possibility that conditions which result from policy changes may lead to innovations. Optimally designed monetary policy is based on a model or hypothesis about behavior by households, firms, and financial institutions in an economy. When innovations occur, behavior by some of these decisionmakers is modified. A model that fails to allow for such change is misspecified and cannot be trusted to guide policymakers.

Depending upon the nature of innovations, policy based on the misspecified model can err in a variety of ways. If an innovation leads to the formation of a new financial institution or financial instrument, obviously the misspecified model can say nothing about either. Drawing upon results from the optimal control literature, the appendix provides an impressionistic discussion of three slightly more tractable cases in which a single parameter in a model is assumed, alternatively, to be random, proportional to some exogenous variable in the model, or proportional to some endogenous variable in the model. The last is argued to be similar in spirit to the rational expectations hypothesis. The conclusion to be drawn from the discussion in the appendix is that the problem of attempting to design optimal monetary policy has been considerably complicated by the presence of changing parameters, whatever their source.

It is not a conclusion that such adversity leads inevitably to inactivity, constant money growth rates, and the demise of discretion. Paleontology teaches us that the only viable option is to adapt to changing circumstances. The challenge is to understand the nature of change and to respond as well as the available information permits. 


\section{A Simple Example of Innovation}

Suppose a central bank has a single policy instrument, $H$, the volume of outside money, which it controls perfectly. In this example banks are assumed always to be at the limit of their capacity to lend and households desire no currency; the required reserves of the banking system equals the volume of outside money. The banking system is assumed to be purely competitive and to have an aggregative balance sheet like the following.

\begin{tabular}{l|c}
\multicolumn{1}{c|}{ Assets } & \multicolumn{1}{c}{ Liabilities } \\
\cline { 2 - 2 } $\begin{array}{l}\text { Reserves } \\
\text { Loans }\end{array}$ & $\begin{array}{l}\text { Demand deposits } \\
\text { Borrowings (after an } \\
\text { innovation occurs) }\end{array}$ \\
\hline
\end{tabular}

Deposits are subject to a reserve requirement, $r$, and initially are the only liability the banks have. Bank borrowing is an innovation that is offstage waiting to happen; borrowings are not subject to reserve requirements. The innovation is assumed to be irreversible. Once it happens everyone can see the value of it, but it will not be made until set-up costs for promotion, legal investigations, and the establishment of a secondary market can be recouped. The interest rate paid on borrowings is equal to the interest rate earned on loans because the cost of intermediating at the margin is assumed to be negligible. The interest rate that banks implicitly pay on demand deposits is assumed always to be less than the loan rate.

The demand for deposits (or M1) by the public is given by

$$
M_{D}=a_{0}-a_{1} i+a_{2} Y+u,
$$

where

$i=$ interest rate on loans

$Y=$ nominal value of national income

$u=$ a random variable.

The demand for loans by the public is given by

$$
L_{D}=b_{0}-b_{1} i+b_{2} Y+v,
$$

where $v$ is another random variable.

By taking into account the banking system's two balance sheet identities, $L_{S}=H(1-r) / r$ and $M_{S}=H / r$, and assuming that the loan and 
money markets clear, the system can be solved for $Y$ and $i$. In such a simple model, a few conditions on parameters are required to assure that an increase in outside money will cause income to rise and the interest rate to fall. Before the innovation occurs, the following conditions on outside money multipliers are sufficient:

$$
\frac{\partial i}{\partial H}=\frac{a_{2}(1-r)-b_{2}}{r\left(a_{1} b_{2}-b_{1} a_{2}\right)}<0, \quad \frac{\partial Y}{\partial H}=\frac{a_{1}(1-r)-b_{1}}{r\left(a_{1} b_{2}-b_{1} a_{2}\right)}>0 .
$$

An innovation is assumed to occur if $i$ ever rises above some threshold level, $i_{T}$, because then loan income can be seen to cover set-up costs in this myopic world. ${ }^{2}$ If the innovation occurs, borrowings become positive and thereafter the amount of borrowed funds that the public supplies to banks is given by

$$
B_{S}=c_{0}+c_{1} i+c_{2} Y+w,
$$

where $w$ is a random variable. Other parameters in the model would probably change after the innovation occurs, depending on how the public trades off bank borrowings with demand deposits, loans, and physical capital. For simplicity, this potentially serious complication is ignored in the present discussion. ${ }^{3}$ In general, the system is still closed because one more equation and one more unknown have been added. The condition for clearing the loan market becomes $L_{S}=\mathrm{H}(1-r) / r+B_{s}$. After the innovation the outside money multipliers of the interest rate, income, and borrowings are

$$
\begin{aligned}
\frac{\partial i}{\partial H} & =\frac{a_{2}(1-r)-\left(b_{2}-c_{2}\right)}{r\left[a_{1}\left(b_{2}-c_{2}\right)-a_{2}\left(b_{1}+c_{1}\right)\right]}, \\
\frac{\partial Y}{\partial H} & =\frac{a_{1}(1-r)-\left(b_{1}+c_{1}\right)}{r\left[a_{1}\left(b_{2}-c_{2}\right)-a_{2}\left(b_{1}+c_{1}\right)\right]}, \\
\frac{\partial B}{\partial H} & =\frac{(1-r)\left(c_{1} a_{2}+c_{2} a_{1}\right)-b_{2} c_{1}-b_{1} c_{2}}{r\left[a_{1}\left(b_{2}-c_{2}\right)-a_{2}\left(b_{1}+c_{1}\right)\right]} .
\end{aligned}
$$

Even in this simplest case it is not possible to assign positive or nega-

2. If interest rates were not sufficiently flexible to clear markets, a resulting "credit crunch" could also precipitate an innovation. See Albert M. Wojnilower, "The Central Role of Credit Crunches in Recent Financial History," BPEA, 2:1980, pp. 277-326.

3. With the assumptions in the text, deposits and borrowings are neither substitutes nor complements and the innovation is unambiguously expansionary. The volume of loans supported by outside money, $H$, is not diminished by the innovation, and all borrowings are matched by loans. 
tive signs to changes in the first two M1 multipliers when the inequalities in equation 3 are satisfied. The sign of the third multiplier cannot be determined without information about the ratio of $c_{1}$ to $c_{2}$. Because the relation between $\mathrm{M} 1$ and $H$ is unaffected by the innovation, corresponding indeterminacies exist for the three M1 multipliers.

Policy actions can still be helpful after an innovation has occurred if the signs of the multipliers themselves are known to be unchanged. The consequences of policy actions are likely to be less predictable because parameter values in equation 4 are likely to be unknown. The degree of predictability is smaller the larger the absolute values of the parameters. All innovations discussed below started on a small scale; thus for several years parameters such as $c_{0}, c_{1}$, and $c_{2}$ were small in absolute value and not likely to have reversed the signs of multipliers in a static model. ${ }^{4}$

By assumption the innovation in this discussion came from allowing the interest rate to exceed a particular threshold level. The innovation could have been prevented by allowing the supply of outside money to increase, but at the cost of experiencing a higher level of nominal income. There is a trade-off between the achievement of short-run targets in nominal income and the preservation of a given financial institutional structure. Random developments, expressed in the shock terms in behavioral equations, could cause the innovation to occur at any time; but policy can make it happen. Keeping interest rates under control reduces the rate of innovation but limits the contribution that monetary policy can make toward achieving stabilization goals in the short run. By intentionally missing some short-run goals, the monetary authorities can better control the system over time.

The usefulness of monetary aggregates as a guide to monetary policy would be further compromised if it were determined that borrowings belong in the definition of money. The reason is that there would no longer be a known relation between the policy instrument and money.

As Marschak suggests, with sufficient thought and observation the postinnovation multipliers might eventually be estimated. ${ }^{5}$ Data would

4. In the appendix to this paper it is argued that a different conclusion about impact multipliers is likely to occur in a dynamic model.

5. Jacob Marschak, "Economic Measurements for Policy and Prediction," in William C. Hood and Tjalling C. Koopmans, eds., Studies in Econometric Method (John Wiley, 1953), pp. 1-26. 
need to be collected rapidly after an innovation is thought to have occurred. In this case, monetary policy could be conducted as it was in the preinnovation period. On the other hand, there are likely to be many such "ratchet" innovations standing in the wings; it seems more plausible that high and fluctuating interest rates, policy-induced or not, will persistently keep policymakers somewhat in the dark.

\section{Innovations in the Postwar Period}

The preceding example and the discussion in the appendix suggest that innovation can disrupt the conduct of monetary policy when policy is optimally designed based on a previously reliable macroeconomic model. Actual monetary policy is not premised on the existence of such a model. The Federal Reserve's model does provide numbers that are available at meetings of the Federal Open Market Committee, but that model is certainly not accepted uncritically. Nevertheless, it is a convenient fiction to think that policy is conducted in the optimal manner. Therefore, in the remainder of this paper the term model refers to this hypothetical construct rather than to any real-world counterpart.

Innovations take many forms and are made by different individuals and firms in an economy. The next section discusses seven major innovations that have occurred in the past twenty years. All have profoundly affected U.S. financial markets and intermediaries but in very different ways. Commercial banks have been the principal innovators in three cases: negotiable certificates of deposit, one-bank holding companies, and Eurobranching. Political pressures have led Congress and two administrations to establish federal credit programs that provide a variety of intermediation services. Securities dealers were primarily responsible for developing repurchase agreements, but commercial banks and their customers made them quantitatively important for interpreting monetary policy. Brokerage firms created money-market mutual funds. The Chicago Board of Trade established financial-instrument futures markets.

The descriptions of innovations that follow contain a great amount of institutional detail, but the underlying proposition is that each of the innovations is likely to have changed behavioral relations importantly in the model linking monetary policy instruments to the rest of the economy. Because the characteristics of the model and, indeed, much relevant in- 
formation about individual innovations are not known, it is not possible to test this proposition directly. Interest rates and some other fragmentary time series are used to illustrate how the innovations have affected money and capital markets in the United States.

The last section draws some conclusions about the consequences of these innovations. It focuses briefly on recognition lags, on the dangers of using monetary aggregates as indicators, on innovation and the structure of interest rates, and on deregulation.

\section{ORIGINS}

Financial institutions alleviate the burdens of wealth holding and improve the allocation of investment flows. They exist because borrowers and lenders have incomplete information about each other and their activities and because of economies of scale in data processing and risk bearing. In part, information is incomplete because it is prohibitively expensive to accumulate and sort all that might be known about people. If all people and activities could be viewed as drawn from a stationary probability distribution, knowledge about the distribution would increase with the passage of time and financial markets would change. In the absence of risk aversion, one would expect financial institutions to wither away as if they were a state described in Das Kapital. In these circumstances an economist might be justified in viewing changes in the financial market as technical progress since change is a consequence of an improved sorting process.

A more important explanation of incomplete information, in my view, is that people and their activities are not reasonably viewed as drawn from a stationary distribution. People are born and die, and scientific advances change the opportunities available to people who borrow and lend. The fact that the relevant distributions are not stationary raises profound questions about the scientific foundations of economic science and statistical method that are beyond the scope of this paper. When financial markets make a contribution in a nonstationary world, it is by anticipating how technology and people are evolving.

Changes in financial markets reflect these underlying technological changes; they also reflect environmental changes that involve the mix of assets, regulations, and market power in a society. At the cost of oversimplifying, the major innovations in the past twenty years are interpreted 
here as resulting from a small number of underlying forces: rising and increasingly volatile nominal interest rates, regulations and regulatory changes, and ambiguities in domains of surveillance by monetary and fiscal authorities. Technical progress in data processing has also been important in increasing the pace of innovation.

The history of financial markets since 1945 is a blend of recovery from gross distortions that were introduced by the Great Depression and World War II and an extremely spirited struggle for market shares under a disintegrating regulatory fabric. Between 1945 and sometime between 1957 and 1962, U.S. depository institutions moved from a position of gross portfolio disequilibrium toward a situation approaching a balanced competitive struggle. During this fifteen-year period, innovations were relatively infrequent and interest rates slowly drifted upward; commercial banks reduced the fraction of their portfolio held as U.S. government securities and chose to forgo matching the high interest rates on time and savings deposits that were being offered by thrift institutions. As interest rates rose, institutions such as the federal funds market became more active.

Commercial banks apparently abstained from competing for time and savings deposits with interest rates during the early part of this period because they had an ample stock of securities to liquidate and because they had a large market share of consumer deposits. Savings and loan associations had been crippled by the depression and war much more than commercial or mutual savings banks. Beginning in 1945, savings and loan associations paid relatively high interest rates and began to grow rapidly. However, for many years their share of deposits in local markets was so small that it was not profitable for banks to match the interest rates being offered. Banks would have had to bid up their own costs substantially in an attempt to ward off these small aggressive institutions. The marginal cost of funds would have been enormous because the same rate of interest would have had to be paid on similar deposits. Commercial banks would also have implicitly encouraged their customers to shift from demand deposits to their own time and savings accounts if they chose to fight-incurring a deadweight loss. However, as the market shares of savings and loan associations increased, the pool of deposits that banks could win rose in different local markets, and the expected cost of incremental deposits attracted through a small rate increase declined. When commercial banks chose to retaliate with interest rates, 
Table 1. Interest Differentials and Commercial Banks' Share of Savings and Time Deposits, 1952-68

Percent unless otherwise specified

\begin{tabular}{|c|c|c|c|c|}
\hline \multirow[b]{2}{*}{ Year } & \multicolumn{2}{|c|}{ Interest rates paid } & \multirow{2}{*}{$\begin{array}{c}\text { Rate } \\
\text { premiums } \\
\text { at savings } \\
\text { associations } \\
\text { (percentage } \\
\text { points) }\end{array}$} & \multirow[b]{2}{*}{$\begin{array}{l}\text { Commercial } \\
\text { banks' share of } \\
\text { all over-the- } \\
\text { counter savings }\end{array}$} \\
\hline & $\begin{array}{c}\text { Savings } \\
\text { accounts } \\
\text { at savings } \\
\text { associations }\end{array}$ & $\begin{array}{c}\text { Time and } \\
\text { savings deposits } \\
\text { in commercial } \\
\text { banks }\end{array}$ & & \\
\hline 1952 & 2.7 & 1.2 & 1.5 & 46.0 \\
\hline 1953 & 2.8 & 1.2 & 1.6 & 44.8 \\
\hline 1954 & 2.9 & 1.3 & 1.6 & 43.4 \\
\hline 1955 & 2.9 & 1.4 & 1.5 & 41.6 \\
\hline 1956 & 3.0 & 1.6 & 1.4 & 40.2 \\
\hline 1957 & 3.3 & 2.1 & 1.2 & 40.5 \\
\hline 1958 & 3.4 & 2.2 & 1.2 & 40.7 \\
\hline 1959 & 3.5 & 2.4 & 1.1 & 39.8 \\
\hline 1960 & 3.9 & 2.6 & 1.3 & 39.1 \\
\hline 1961 & 3.9 & 2.7 & 1.2 & 39.9 \\
\hline 1962 & 4.1 & 3.2 & 0.9 & 41.5 \\
\hline 1963 & 4.2 & 3.3 & 0.9 & 41.7 \\
\hline 1964 & 4.2 & 3.4 & 0.8 & 42.3 \\
\hline 1965 & 4.2 & 3.7 & 0.5 & 43.8 \\
\hline 1966 & 4.5 & 4.0 & 0.5 & 45.0 \\
\hline 1967 & 4.7 & 4.2 & 0.5 & 46.1 \\
\hline 1968 & 4.7 & 4.5 & 0.2 & 47.0 \\
\hline
\end{tabular}

Source: United States League of Savings Associations, '74 Savings and Loan Fact Book (Chicago: USL, 1974), pp. 15, 17.

a. The difference between the interest rates paid on accounts at savings associations and that paid on time and savings deposits in commercial banks.

the nationwide erosion of the market share of commercial banks came to an abrupt halt, as is shown in table 1. Between 1956 and 1962 the difference in savings deposit yields paid by commercial banks and savings and loan associations shrank by more than one-third.

The decision by commercial banks to meet the competition marked a turning point that was soon evident on other fronts, and may have unleashed interest rates whose volatility began to increase.

\section{NEGOTIABLE CERTIFICATES OF DEPOSIT}

The emergence of negotiable certificates of deposit has a similar background. The volume of commercial paper outstanding approximately doubled between 1957 and 1961, partly because the interest rates on 
commercial paper were attractive relative to other low-risk, short-term assets and partly because credit rationing appeared to threaten the supply of credit to large sales-finance firms that had access to that market. Commercial paper is a partial alternative to bank intermediation between very large corporations because funds flow directly between corporations; it is not a full displacement of banks because it must be backed by bank lines of credit in order to have a prime credit rating. Nevertheless, the threat was clear and in February 1961 two large eastern banks, together with the Discount Corporation of New York, established a secondary market in large-denomination corporate time certificates of deposit. This action constituted a dramatic reversal of the long-standing policies of many large banks of discouraging and even refusing to accept corporate time deposits. It was successful in the sense that the volume of outstanding certificates of deposit soon exceeded the volume of commercial paper, so that the banks' market share of intermediation among large corporations was effectively protected. Subsequently banks and their parent holding companies borrowed on an unsecured basis from large corporations and issued their own bank-related commercial paper.

There appear to be three principal reasons why negotiable certificates of deposit emerged when they did. First, banks made a preemptive move to deter a potent rival, commercial paper. Market share was a prime consideration, as it was in the struggle for consumer deposits. Second, many interest rates had reached postwar peaks in late 1959, and the possibility that this event would recur could not be excluded. There had always been a demand for interest-bearing negotiable assets, and the recent events had caused that demand to increase. Finally, the continuing decline in the fraction of bank portfolios held in U.S. government securities meant that commercial banks' own secondary reserve was being depleted. They needed a buffer, and a market that permitted large banks to bid competitively for medium-term funds was attractive. It is noteworthy that shortly after the emergence of certificates of deposit, banks began to increase their holdings of tax exempt securities, which were very high yielding (after-tax) assets but never convenient as secondary reserves.

Individual banks began to issue negotiable certificates of deposit because they needed to protect themselves and their customers from episodes of excess loan demand and associated surges in interest rates that led to sizable deposit withdrawals, but not because of regulatory changes 
or ambiguities about regulations. When certificates first appeared, they were subject to the 5 percent reserve requirement that applied to time and savings deposits at member banks and the regulation Q ceiling. During those years the ceiling was routinely raised by the Federal Reserve whenever it threatened to become binding. The reserve requirement did put certificates at a slight disadvantage relative to commercial paper, but those certificates were highly liquid and more divisible than commercial paper. Certificates attracted funds that banks could lend for several months. The ability of the banks to forestall deposit withdrawals by large depositors was enhanced and the volume of funds available to banks became more predictable; the innovation was expansionary because increasing amounts of funds were subsequently funneled into relatively efficient intermediaries.

Restrictive monetary policy was slightly weakened by this innovation because banks could respond more flexibly to policy-induced increases in interest rates and excess demand for loans by raising the rate at which they offered new certificates. A bank needed only to bid up interest rates to attract funds and, therefore, it never had to reject valued customers through involuntary loan denials. Only a short time passed before the Federal Reserve performed a daring experiment: it plugged the only safety valve banks had by freezing the regulation Q ceiling in 1966.

\section{ONE-BANK HOLDING COMPANIES}

The initial response to the apparently unanticipated inflexibility of the regulation $\mathrm{Q}$ ceiling was to avoid it by having a bank go through a congeneric transformation to form a one-bank holding company. This tactic allowed banks to raise funds at market interest rates by issuing commercial paper or by other borrowing that was not subject to ceilings or indeed even to monitoring by the Federal Reserve. To be sure, banks did not convert the instant the problem arose; many of their customers were probably denied credit or had their credit rationed, and a number of new compensating balance arrangements were introduced. Savings and loan associations were even less deft and, therefore, the mortgage and housing markets were crippled by disintermediation as the Federal Reserve and large government borrowings forced market interest rates upward.

As in the case of certificates of deposit, the process of converting did 
not stop when market interest rates fell below regulation $Q$ ceilings in early 1967. Banks recognized that the condition of a binding ceiling might recur and congeneric conversions were time-consuming. The Federal Reserve vainly sought to have the Bank Holding Company Act amended as it had since 1956. Finally in 1970 Congress did amend the act, and the Federal Reserve's regulatory reach was extended to include activities of one-bank holding companies. ${ }^{6}$ The monetary authority did manage to impose reserve requirements on debt issued by holding companies before the act was amended and was partly successful in preventing banks from transferring assets to their holding-company affiliates when the purpose was to avoid regulation $\mathrm{Q}$ ceilings.

Although one-bank holding companies had existed for many years in the United States, they controlled small banks and represented no threat to monetary policy. The innovation that occurred in 1966 was to recognize that large banks could avoid controls through regulation $\mathrm{Q}$ ceilings by exploiting this legal form. The innovation occurred because market interest rates rose above the ceiling, and banks recognized that holding companies could avoid both regulation and surveillance. Banks wanted the capability to accommodate the loan requests of their good customers. The change was irreversible; congeneric holding companies remained after regulation $Q$ ceilings were removed from large certificates of deposit and they will remain after (if ever) regulation $Q$ ceilings are removed from consumer deposits under the Depository Institutions Deregulation and Monetary Control Act of 1980.

The congeneric conversion episode has been more damaging for monetary control than the emergence of certificates of deposit. After the regulation $\mathrm{Q}$ ceiling was allowed to become binding, a misplaced emphasis on and confidence in the ability of the Federal Reserve to control aggregates like M2 and M4 developed. The Federal Reserve could obviously influence these quantities through regulation $\mathrm{Q}$, but it could not control the sum of either M2 or M4 and the close substitutes that were being issued by nonbank affiliates of holding companies. The monitoring ability of the central bank was impaired because holding-company affiliates that were not banks did not (and do not) report their activities in a timely fashion. Consequently, the belated attempts by the Federal Re-

6. Before the 1970 amendments the Federal Reserve had no supervisory authority over a bank holding company unless it had 25 percent or more of the stock of at least two commercial banks. 
serve to impose reserve requirements on bank-related paper were transparently stopgap measures.

Even though the Bank Holding Company Act was amended, the episode has seriously damaged the Federal Reserve's credibility. It has established an impression that holding companies could do what they could get away with and, therefore, has forced the monetary authority into the unenviable position of having to be the final arbiter of an endless series of seemingly plausible schemes. Whatever is approved will never be sensibly depicted in a macroeconomic model unless committee decisionmaking by the Federal Reserve Board achieves an unprecedented degree of transitivity. Further, the fragility of the financial system has been increasing because the leverage in bank holding companies-the ratio of debt to equity-is higher than it is in the banks they control. The Federal Reserve is not likely to act aggressively if such actions endanger the solvency of large financial institutions.

\section{EUROBRANCHES AND FOREIGN BANKING}

In addition to congeneric transformations, in 1966 and increasingly thereafter many large commercial banks in the United States established branches offshore. With the exception of overnight deposits held in Caribbean branches, deposits in foreign branches of U.S. banks are excluded from monetary aggregates that the Federal Reserve publishes. Deposits in foreign branches tend to be very short-term time deposits, which earn interest at a rate that is determined daily in London. Because branches are viewed as operating under the banking laws of the country in which they are located, their deposits are exempt from U.S. reserve requirements and regulation $\mathrm{Q}$. An overseas branch may exist physically in some foreign country or simply be a "shell" that exists in the computer at the head office of a large U.S. bank. At the end of 1965 there were 211 overseas branches of U.S. commercial banks that belonged to the Federal Reserve System; 177 of these were branches of one bank, the First National City Bank of New York. The number of overseas member bank branches rose to 244 at the end of 1966, 295 at the end of 1967, and 375 at the end of 1968 . By the end of 1972, 107 member banks were operating 627 foreign branches. The assets of overseas member bank branches increased eightfold during the seven-year period and exceeded 10 percent of the domestic assets of member banks in 1972. This explosion is the inter- 
national counterpart of the one-bank holding company episode. ${ }^{7}$ There was no correspondingly large increase in gross capital expenditures by foreign affiliates of U.S. firms or in the sum of U.S. imports and exports.

Large banks borrowed extensively in the Eurodollar market whenever the regulation $\mathrm{Q}$ ceiling on certificates of deposit was binding during the late 1960s. In 1969 the Federal Reserve imposed 10 percent marginal reserve requirements on Eurodollar borrowings and issued the "Martin letter," a letter from Chairman William McChesney Martin, Jr., to member banks, which asked that activities of offshore branches be confined to developing new international business and not be used for shifting deposits away from domestic reserve requirements or otherwise avoiding domestic monetary control. Eurodollar borrowings by domestic banks fell immediately after these actions and, perhaps in a spirit of compromise, the Federal Reserve eliminated its regulation $\mathrm{Q}$ ceiling for shortterm certificates of deposit. However, the number of U.S. banks with foreign branches, the number of foreign branches, and the total assets at foreign branches of U.S. banks have risen rapidly in subsequent years. There have been further large fluctuations in Eurodollar borrowings by domestic banks, continuing changes in reserve requirements on Eurodollar borrowings, and a letter to banks from Chairman Arthur F. Burns, which reemphasized the position previously taken by Chairman Martin. Moreover, there is reason to believe that lending by offshore branches to foreign affiliates of U.S. corporations has consequences for U.S. policy; funds are surely fungible among branches of a multinational bank or subsidiaries of a nonfinancial corporation.

A further reverberation from this explosion involved foreign banks, which apparently were responding to the international expansion of U.S. banks. Most deposits in U.S. chartered subsidiaries of foreign banks are included in U.S. monetary aggregates. Until the passage of the International Banking Act in 1978, deposits of branches and agencies of foreign banks were excluded from aggregates. Between 1972 and 1979 the number of offices of foreign banks tripled in the United States, and

7. See also the discussion in Donald D. Hester, "The Effects of Eurodollar and Domestic Money Market Innovations on the Interpretation and Control of Monetary Aggregates," SSRI Workshop Series 8005 (University of Wisconsin-Madison, Social Systems Research Institute, April 1980), in Raymond E. Lombra and Willard E. Witte, eds., The Political Economy of Domestic and International Monetary Relations (Iowa State University Press, forthcoming). 
the assets of these offices sextupled. At the end of 1979 only about onefifth of their $\$ 168$ billion in assets was backed by nonbank U.S. domestic deposits, yet these banks held 40 percent of commercial and industrial loans that were in portfolios of commercial banks in New York and California. The loans of these foreign banks were largely financed by borrowing from Europe. Until the passage of the International Banking Act, this substantial volume of intermediation by foreign banks was not closely monitored and certainly was not picked up in large macro models of the economy.

Foreign branches of U.S. banks and U.S. branches of foreign banks existed before 1966, but events in that year hastened their development and probably permanently altered the nature of their activities. As in the case of bank holding companies, the factors leading to these innovations were high and volatile interest rates that rose above the regulation $\mathbf{Q}$ ceiling, avoidance of regulations involving reserve requirements and interest rate ceilings, and avoidance of surveillance by monetary authorities. However, the weighting of these factors was probably different. In particular, it is awkward for the Federal Reserve to attempt to monitor activities of foreign branches of U.S. banks; such probing could easily appear to be a violation of the sovereignty of another country. In addition, advances in data processing were undoubtedly important for coordinating multinational banking networks. The Clearing House Interbank Payments System, which is an automated mechanism critically involved in Eurodollar transactions, was activated in 1970.

The International Banking Act could not really address the growing difficulty of controlling domestic economic activity. International banking is a complex scene in which corporations and banks seem able to exploit the regulations (or lack thereof) of one country to get around those of another country. Ambiguities in the domains of surveillance by different central banks and governments are common. The effects of monetary policy actions have become less predictable as banks and nonfinancial corporations increasingly exploit these ambiguities.

REPURCHASE AGREEMENTS AND NET

FEDERAL FUNDS PURCHASED

Repurchase agreements are transactions in which a bank or security dealer sells U.S. Treasury or agency securities to a firm, government, or 
individual for a short period and simultaneously commits itself to reacquire these securities at an agreed price. These arrangements were developed by nonbank security dealers at about the time of the "accord" as an inexpensive mechanism for financing their inventories. The Federal Reserve first reported using them for Treasury securities in 1950 and for agency securities in 1967. In late 1968 commercial banks were again subject to binding regulation $Q$ ceilings for certificates of deposit. On this occasion a number of large banks began to emulate dealers and the Federal Reserve by arranging short-term repurchase agreements in large denominations to reduce their reserves obligation, since funds borrowed through repurchase agreements had no reserve requirements. (Funds acquired through repurchase agreements are not subject to interest rate ceilings.) Initially banks were using many different kinds of assets as collateral for repurchase agreements, but in mid-1969 the Federal Reserve clarified its regulation $\mathrm{D}$ to state that only borrowed funds secured by Treasury and agency securities would be exempt from reserve requirements.

From the perspective of a firm or state government accepting securities in an overnight repurchase agreement, this innovation was a boon-its demand-deposit balance was reduced at the close of a business day and was restored at the beginning of the following day. Consequently, access to deposit funds was not diminished and interest was earned at a rate that was slightly lower than the federal funds rate. In actuality, although not in law, interest was being paid on demand deposits. When interest rates fell in 1970, banks largely withdrew from the business of arranging repurchase agreements. However, record high interest rates in 1973 and 1974 and competition from securities dealers again led banks to acquire large volumes of funds through repurchase agreements; and, at about that time, estimated money-demand functions began to disintegrate. ${ }^{8}$ Since then repurchase agreements have been prominent in money markets.

In addition to borrowing funds through repurchase agreements, member banks began to borrow federal funds on an unsecured basis from a large number of other financial institutions and government agencies during 1968 and 1969. The amounts of federal funds acquired by member banks cannot be distinguished from funds obtained through repurchase agreements in publicly available data. On the basis of two cross-section

8. See Stephen M. Goldfeld, "The Case of the Missing Money," BPEA, 3:1976, pp. $683-730$. 
surveys of forty-six large banks in 1974 and 1977, federal funds borrowing from other than member banks appeared to be of the same magnitude as the volume of repurchase agreements. ${ }^{9}$ Bank call reports began to include information on the sum of net federal funds purchased by commercial banks and net funds acquired through repurchase agreements (hereafter net purchased funds) during the 1960s. For all commercial banks this quantity was, at year-end, $\$ 0.3$ billion in $1965, \$ 3.2$ billion in 1970 , and $\$ 19.7$ billion in 1975 . The amount was $\$ 52.1$ billion in June 1978 , when the call report was modified, making the continuation of this series impossible.

The origins of short-term net purchases of federal funds by banks are unclear. Several legal opinions by the Federal Reserve and the comptroller of the currency were required to legitimize this practice, and much testing of regulatory waters by banks, other financial institutions, and government agencies occurred before an interpretation was published in the January 1970 Federal Reserve Bulletin that clarified what constituted federal fund transactions. ${ }^{10}$ These regulatory changes were an essential element leading to the evolution of net purchased funds. ${ }^{11}$

The rapid growth of net purchased funds appears to have been stimulated primarily by high short-term interest rates that emerged in 1969, 1973, and 1974. Competitive pressures from securities dealers, very aggressive corporate treasurers and managers of government agencies, and a shortage of deposit funds forced banks to purchase federal funds from firms and governments that had previously held bank deposits. When interest rates fell in 1970, banks briefly were able to reduce their purchases, so in the early stages this change in practice was reversible. A

9. Wayne J. Smith, "Repurchase Agreements and Federal Funds," Federal Reserve Bulletin, vol. 64 (May 1978), pp. 353-60.

10. "Interpretation of Regulation Q," Federal Reserve Bulletin, vol. 56 (January 1970), pp. 38-39.

11. A summary of this sequence of legal opinions appears in Hester, "Effects of Eurodollar and Domestic Money Market Innovations." The 1970 interpretation provided the conditions under which federal funds borrowing would be exempt from regulations $\mathrm{D}$ and $\mathrm{Q}$ and required that the notion of a bank be redefined. $\mathrm{A}$ bank was defined to include member commercial banks, nonmember commercial banks, Edge Act and Agreement corporations, branches and agencies of foreign banks, savings banks, building or savings and loan associations, and cooperative banks. Also exempt from the regulations were purchases and sales by the Export-Import Bank, the Minbanc Capital Corporation, federal agencies, and nonbank security dealers. In 1979 the definition was extended to include credit unions. 
small decline also occurred after the peak of interest rates in 1974, but this time banks were not successful in eliminating the practice of buying short-term funds from corporations and governments. It appears as though the practice is a permanent change and thus qualifies as an innovation.

Table 2 presents measures of financial market activity that reflect growth in net purchased funds since 1970, including demand-deposit turnover. This measure is the ratio of demand-deposit account debits (expressed at an annual rate) to demand deposits, excluding U.S. government and interbank accounts. Over the postwar period, demand-deposit turnover has been showing an upward trend. The turnover rate rose from 17.6 times per year in 1945 to 47.7 in 1964 when the series was revisedan annual rate of growth of about 5.4 percent; between 1964 and 1970 a comparable measure grew 8.5 percent annually. The turnover shown in table 2 grew 11.6 percent a year from June 1970 to June 1977 and 14.6 percent a year between June 1977 and June 1980. Part of the upward trend in turnover can be explained by rising interest rates; but that can be only a small part of the explanation because rates were lower in 1977 than they were in 1969. Another part of the explanation comes from the growth in repurchase agreements. Deposit accounts of corporations and state and local governments must be debited in order for them to participate in a repurchase agreement. The annualized volumes of debits use 1 in calculating the reported turnover rates rose from $\$ 10$ trillion in 1970 to $\$ 62$ trillion in 1980 . A substantial fraction of this increase is probably attributable to the increasing volume of repurchase agreements. For example, if the outstanding volume of overnight repurchase agreements were $\$ 40$ billion, they alone would imply an annualized volume of debits over 250 business days of $\$ 10$ trillion. In table 2 very large increases in deposit turnover occurred between December 1972 and December 1974 when the reported net purchased funds approximately doubled. ${ }^{12} \mathrm{~A}$ similarly large increase in turnover occurred between December 1975 and June 1977, when net purchased funds again approximately doubled. Judging from the substantial increase in deposit turnover between De-

12. Call report information, because it pertains to a single day, is extraordinarily vulnerable to "window dressing." It is a serious defect of almost all published information about repurchase agreements that it is based upon single-day figuresusually Wednesdays. The volume of repurchase agreements on Wednesdays is likely to be much smaller than on weekends when three days' funds can be acquired for a single day's brokerage charges. 
Table 2. Measures of Financial Activity in Money Markets, 1970-80a

\begin{tabular}{|c|c|c|c|c|c|}
\hline \multirow{2}{*}{$\begin{array}{l}\text { Year } \\
\text { and } \\
\text { month }\end{array}$} & \multirow{2}{*}{$\begin{array}{l}\text { Net purchased } \\
\text { funds (billions } \\
\text { of dollars) }\end{array}$} & \multirow{2}{*}{$\begin{array}{l}\text { Demand- } \\
\text { deposit turn- } \\
\text { over (ratio) }\end{array}$} & \multicolumn{2}{|c|}{ Number of funds transfers } & \multirow{2}{*}{$\begin{array}{l}\text { Changes in } \\
\text { system open- } \\
\text { market } \\
\text { account } \\
\text { (billions of } \\
\text { dollars) }\end{array}$} \\
\hline & & & $\begin{array}{c}\text { Wire } \\
\text { (millions) }\end{array}$ & $\begin{array}{l}\text { Check } \\
\text { (billions) }\end{array}$ & \\
\hline $\begin{array}{l}\text { 1970: June } \\
\text { December }\end{array}$ & $\begin{array}{l}4.5 \\
3.2\end{array}$ & $\begin{array}{l}73.1 \\
77.0\end{array}$ & 7 & 7.2 & $\begin{array}{l}0.6 \\
0.7\end{array}$ \\
\hline $\begin{array}{l}\text { 1971: June } \\
\text { December }\end{array}$ & $\begin{array}{l}5.6 \\
6.9\end{array}$ & $\begin{array}{l}80.4 \\
83.7\end{array}$ & 8 & 7.7 & $\begin{array}{l}0.9 \\
1.0\end{array}$ \\
\hline $\begin{array}{l}\text { 1972: June } \\
\text { December }\end{array}$ & $\begin{array}{r}11.6 \\
9.5\end{array}$ & $\begin{array}{l}84.8 \\
90.7\end{array}$ & 9 & 8.5 & $\begin{array}{l}1.2 \\
0.5\end{array}$ \\
\hline $\begin{array}{l}\text { 1973: June } \\
\text { December }\end{array}$ & $\begin{array}{l}16.8 \\
19.0\end{array}$ & $\begin{array}{r}99.9 \\
110.2\end{array}$ & 12 & 10.0 & $\begin{array}{l}1.4 \\
1.4\end{array}$ \\
\hline $\begin{array}{l}\text { 1974: June } \\
\text { December }\end{array}$ & $\begin{array}{l}25.5 \\
18.5\end{array}$ & $\begin{array}{l}116.9 \\
128.0\end{array}$ & 15 & 10.8 & $\begin{array}{l}1.0 \\
1.8\end{array}$ \\
\hline $\begin{array}{l}\text { 1975: June } \\
\text { December }\end{array}$ & $\begin{array}{l}22.4 \\
19.7\end{array}$ & $\begin{array}{l}124.4 \\
131.0\end{array}$ & 17 & 11.4 & $\begin{array}{l}2.2 \\
2.6\end{array}$ \\
\hline $\begin{array}{l}\text { 1976: June } \\
\text { December }\end{array}$ & $\begin{array}{l}29.8 \\
32.6\end{array}$ & $\begin{array}{l}139.3 \\
153.5\end{array}$ & 21 & 12.3 & $\begin{array}{l}1.9 \\
3.8\end{array}$ \\
\hline 1977: June & 41.7 & $\begin{array}{l}157.7^{\mathrm{b}} \\
133.6^{\mathrm{b}}\end{array}$ & 25 & 13.3 & 3.4 \\
\hline $\begin{array}{l}\text { 1978: June } \\
\text { December }\end{array}$ & $\begin{array}{r}52.1 \\
\text { n.a. }\end{array}$ & $\begin{array}{l}144.4 \\
139.3\end{array}$ & 29 & 14.1 & $\begin{array}{l}3.9 \\
2.5\end{array}$ \\
\hline $\begin{array}{l}\text { 1979: June } \\
\text { December }\end{array}$ & $\begin{array}{l}\text { n.a. } \\
\text { n.a. }\end{array}$ & $\begin{array}{l}167.3 \\
172.4\end{array}$ & 35 & 15.1 & $\begin{array}{l}5.3 \\
2.3\end{array}$ \\
\hline $\begin{array}{l}\text { 1980: June } \\
\text { December }\end{array}$ & $\begin{array}{l}\text { n.a. } \\
\text { n.a. }\end{array}$ & $\begin{array}{l}201.5 \\
222.7\end{array}$ & n.a. & n.a. & $\begin{array}{l}2.3 \\
1.4\end{array}$ \\
\hline
\end{tabular}

Sources: Net purchased funds, demand-deposit turnover, and changes in system open-market accountFederal Reserve Bulletin, various issues; funds transfers-Board of Governors of the Federal Reserve System, 66th Annual Report, 1979, p. 323 and preceding issues.

n.a. Not available.

a. Net purchased funds are the sum of federal funds purchased and funds acquired through repurchase agreements minus funds sold to commercial banks as reported on call reports by all commercial banks. Demand-deposit turnover is the ratio of demand-deposit account debits to demand deposits at selected clearinghouses or banks, excluding interbank and U.S. government debits and accounts. The series was substantially revised in June 1977; the reported rate is for the indicated month but is annualized. The data for funds transfers are numbers of items processed by the Federal Reserve System in the calendar year ending in December. The amount of funds transferred by wire is many times the amount transferred by check. Changes in the system open-market account reflect the mean absolute value of end-of-month changes in the Federal Reserve System's open-market account, measured over the six months ending with the month shown.

b. The first entry for June 1977 shows turnover calculated on the old basis; the second entry is calculated on the new basis. 
cember 1978 and December 1980, it is likely that repurchase agreements again surged during that two-year period.

In order to deal in repurchase agreements, banks must be able to transfer funds expeditiously. Wire transfers can be completed in a few minutes while check transfers require one or more business days. The third and fourth columns in table 2 report the numbers of items transferred by wire and check through the Federal Reserve for calendar years. ${ }^{13}$ The growth rate in the number of wire transfers was particularly high in 1973 and 1974, when the volume of repurchase agreements appears to have risen. Since the end of 1975 , funds transferred by wire have again been growing at a rate of about 20 percent a year, which suggests that repurchase agreements and similarly designed transfers involving Eurodollars`are rising rapidly. The number of checks cleared through the Federal Reserve System has been growing less rapidly than wire transfers. The annual growth rate in the number of checks cleared by the system peaked in 1973 and has been about 7 percent in recent years.

As the private sector became more adept at moving funds, the Federal Reserve found itself increasingly having to intervene in the open market. Sizable increases in its portfolio were followed by substantial liquidations. The last column of table 2 roughly summarizes this activity by reporting over six-month intervals the mean absolute value of monthly changes of securities in the open market account. Between 1970 and June 1979 this measure increased ninefold-much faster than any of the major monetary aggregates. The Federal Reserve was especially active in the market between June 1976 and June 1979 when deposit turnover, net purchased funds, and wire transfers were rapidly expanding. An obvious interpretation is that the underlying innovations were impairing the Federal Reserve's ability to control monetary aggregates such as M1 and M2. The amount of trading activity declined about 40 percent in the last eighteen months shown in the table relative to the preceding three years. ${ }^{14}$ This

13. The growth in wire transfers was greatly facilitated by the establishment of the Culpeper, Virginia, "switch" and related computer facilities in 1971 that sharply reduced costs of wiring funds and securities in the United States.

14. The number of trading interventions also fell by about one-third in the period beginning October 6, 1979, from the level of the previous year. See Fred J. Levin and Paul Meek, "Implementing the New Operating Procedures: The View from the Trading Desk," in New Monetary Control Procedures, Federal Reserve Staff Study (Board of Governors of the Federal Reserve System, 1981), vol. 1, p. 17 a. 
apparently reflects the Board's decision to allow wider swings in interest rates, which was announced in October 1979.

The Federal Reserve does not seem to have appreciated the importance for monetary control of the development of repurchase agreements and net purchased funds. As is argued in the final section of this paper, overnight repurchase agreements are a transactions medium in every conventional sense, but are not included in transactions aggregates such as M1A and M1B. This lapse and its perception by banks and others were important contributors to the growth of net purchased funds. The amount of federal funds supplied to banks by government agencies and others does not appear to be closely monitored by the Federal Reserve, and information about repurchase agreements is in woefully short supply. Surveillance is very limited, a fact that fundamentally impedes efforts to control monetary aggregates. Belated recognition of the Federal Reserve's regulatory lapse may have been indicated by its October 1979 decision to place marginal reserve requirements on net purchased funds, although the requirements were abandoned in the summer of 1980.

\section{MONEY-MARKET MUTUAL FUNDS}

Households and individuals were not able to participate in the game of earning interest on transactions balances through overnight repurchase agreements because denominations of these arranged transactions are frequently very large. An "even lot" may be as high as \$25 million. During 1972 a new class of mutual funds, money-market mutual funds, emerged whose function was to collect household deposits in sums as small as $\$ 1,000$ and invest the proceeds in large-denomination short-term money-market instruments, Treasury bills, commercial paper, and negotiable certificates of deposit. Assets of funds rose until interest rates peaked in 1974, when they were a little less than $\$ 4$ billion. Between 1974 and 1977 assets barely grew, although the number of funds continued to increase. Since early 1978 assets of these funds and the number of funds have grown very rapidly; total assets exceeded $\$ 100$ billion in March 1981. Balances in the funds are typically withdrawable on demand in amounts as small as $\$ 500$ by check or wire. Thus money-market funds provide services to individuals that are very similar to those provided by commercial bank demand deposits, by effectively increasing the divisibility of money-market instruments. They also help large investors 
to acquire a broadly diversified portfolio of indivisible money-market instruments.

Money-market funds emerged because of the growing gap between short-term money-market interest rates and regulatory ceilings that existed at depository institutions on demand, savings, and time accounts. Their development was also facilitated by improvements in wire transfer services. Their principal social contribution is to destroy the effectiveness of regulatory ceilings; they draw funds away from low interest bank accounts and lend the same funds back to banks and others at high interest rates. They are modern-day Robin Hoods who protect the public from a coalition of government and depository institution barons; as in the days of old, they increase social welfare by taking risks. The risks do not appear to be very great. Although there is no protection corresponding to deposit insurance, monetary authorities seem reluctant to allow a major bank to default on its certificates of deposit.

The importance of this large expansion of money-market mutual funds is unclear. They are included in monetary aggregates such as M2. If the sources of funds are household savings and demand-deposit accounts, the meaning of monetary aggregates that include such deposits is being preserved. If, on the other hand, the sources are other money-market instruments, their rapid growth may disrupt monetary control. It is puzzling that they should grow so rapidly if they are not, in fact, substantively distorting flows of funds in the money market.

\section{OFF-BUDGET AGENCIES AND FEDERALLY GUARANTEED LOANS}

A major change in U.S. financial markets was brought about by Congress and the Johnson and Nixon administrations when they greatly expanded the volume of off-budget credit activity. ${ }^{15}$ Briefly stated, government-sponsored agencies intervene in the capital market to increase the flows or reduce the costs of credit to certain specified sectors of the economy, especially agriculture and housing. They operate by making direct

15. A complete analysis of federal credit programs, both on-budget and offbudget, is beyond the scope of this paper. A convenient summary of programs is available in the annual volume, Special Analyses, Budget of the United States Government, Fiscal Year 1982, Special Analysis F, pp. 141-201. 
loans, guaranteeing or cosigning loans that have been made in the private sector, and providing secondary market facilities that make some assets of the private sector more convenient to market or hold. Examples include the Federal National Mortgage Association, the Farm Credit Banks, and the Student Loan Marketing Association. Sponsored agencies issue debt to finance the loans they make; the volume of this debt has quintupled in the past decade. While agencies have existed for many years, most of the outstanding debt has been issued by agencies that were created between 1968 and 1972.

Off-budget federally guaranteed loan programs have about quadrupled in the past decade. Both sponsored agencies and loan guarantee programs provide intermediation services to the public because they modify financial contracts in ways that encourage capital formation and retention. The targets of agencies and guarantee programs are determined by Congress, rather than by the market.

The emergence of many sponsored agencies and guarantee programs in the 1968-72 period appears to reflect several factors: a desire by the government to conceal large budget deficits by privatizing what would otherwise have been included in the federal deficit; strong pressures from the housing industry and thrift institutions, which were particularly crippled in the crunch of 1966; and political expediency, which occurs because government guarantee programs are not required to show their expected losses until realization. Large deficits, a controversial war, and herding instincts induced the government to introduce these programs in a relatively short period. By 1981 the volume of credit outstanding that was supported by sponsored agencies and all guarantee programs exceeded the assets of savings and loan associations, the nation's second largest financial intermediary.

The primary force leading to the establishment of sponsored agency and guarantee programs was almost surely the disintermediation experienced in 1966 by thrift institutions, which in turn was caused by an inflexible deposit rate ceiling and rapidly rising money-market interest rates. Both programs are tautologically a consequence of regulatory changes. Both also seem designed to exploit ambiguities in fiscal surveillance by the public by perverting the budgetary review process. The establishment of sponsored agencies is analogous to a private corporation's spinning off a subsidiary; the balance sheet of the parent firm no longer accurately reflects the combined position of the parent and subsidiary. Guarantee 
Table 3. Residential Mortgage Debt, by Type of Holder, 1972-80a

Billions of dollars unless otherwise specified

\begin{tabular}{|c|c|c|c|c|c|c|}
\hline Year & $\begin{array}{c}\text { Federal and } \\
\text { related } \\
\text { agencies } \\
(1)\end{array}$ & $\begin{array}{c}\text { Major } \\
\text { financial } \\
\text { institutions } \\
\quad(2)\end{array}$ & $\begin{array}{c}\text { All } \\
\text { others } \\
\text { (3) }\end{array}$ & $\begin{array}{c}\text { Total } \\
\text { (4) }\end{array}$ & $\begin{array}{c}\text { Federal } \\
\text { share of } \\
\text { outstanding } \\
\text { debt } \\
(\text { percent }) \\
(5)\end{array}$ & $\begin{array}{l}\text { Federal } \\
\text { share of } \\
\text { annual } \\
\text { change in } \\
\text { debt } \\
\text { (percent) } \\
(6)\end{array}$ \\
\hline 1972 & 41.5 & 346.1 & 66.5 & 454.1 & 9.1 & $22.0^{\mathrm{b}}$ \\
\hline 1973 & 49.4 & 384.8 & 75.1 & 509.3 & 9.7 & 14.3 \\
\hline 1974 & 63.9 & 407.9 & 77.6 & 549.4 & 11.6 & 36.2 \\
\hline 1975 & 79.7 & 433.3 & 78.4 & 591.4 & 13.5 & 37.6 \\
\hline 1976 & 91.8 & 486.1 & 83.1 & 661.0 & 13.9 & 17.4 \\
\hline 1977 & 111.7 & 564.0 & 92.7 & 768.4 & 14.5 & 18.5 \\
\hline 1978 & 137.6 & 643.8 & 104.1 & 885.4 & 15.5 & 22.1 \\
\hline 1979 & 175.4 & 710.0 & 119.7 & $1,005.1$ & 17.5 & 31.6 \\
\hline 1980 & 206.4 & 750.7 & 137.2 & $1,094.3$ & 18.9 & 34.8 \\
\hline
\end{tabular}

Source: Federal Reserve Bulletin, various issues.

a. The debt by federal and related agencies includes mortgage pools or trusts. Major financial institutions include commercial and mutual savings banks, savings and loan associations, and life insurance companies. Column 5 is column 1 divided by column 4 . Column 6 is the first difference of column 1 divided by the first difference of column 4 . All data refer to end of year shown.

b. Constructed using earlier unrevised data.

programs are misleadingly represented in the federal budget because of the dubious underwriting procedure mentioned above.

The consequences of federal credit programs have been to reduce the shares of credit to the agricultural and real estate sectors that are held by banks and thrift institutions and to reduce borrowing costs of these sectors. Table 3 indicates a steadily rising share of mortgage lending that is held or assisted by federal agencies, particularly in years when interest rates are high, such as 1974, 1979, and 1980. Table 4 indicates that the differential between the Federal Home Loan Bank Board effective mortgage loan interest rate and the rate on Moody's Aaa corporate bonds has narrowed in response to federal credit programs. The differential between the mortgage rate and the rate on Baa bonds has shifted from being strongly positive to being predominantly negative, especially in years like 1974, 1975, and 1980.

Because these programs have increasingly shielded housing and agriculture from rising interest rates, they have blunted one of the cutting edges of restrictive monetary policy and redistributed the burden of restrictive policy to other sectors. Larger increases in interest rates will be 
Table 4. Interest Rates on Mortgage Loans and Corporate Bonds, 1963-80

Percent unless otherwise specified

\begin{tabular}{|c|c|c|c|c|c|}
\hline Year & $\begin{array}{c}\text { Moody's } \\
\text { corporate } \\
\text { Aaa }\end{array}$ & $\begin{array}{c}\text { Federal Home } \\
\text { Loan Bank } \\
\text { Board } \\
\text { effective } \\
\text { mortgage rate }\end{array}$ & $\begin{array}{l}\text { Mortgage } \\
\text { premium } \\
\text { (percentage } \\
\text { points) }\end{array}$ & $\begin{array}{c}\text { Moody's } \\
\text { corporate } \\
\text { Baa }\end{array}$ & $\begin{array}{c}\text { Mortgage } \\
\text { premium }^{c} \\
\text { (percentage } \\
\text { points) }\end{array}$ \\
\hline 1963 & 4.35 & 5.89 & 1.54 & 4.85 & 1.04 \\
\hline 1964 & 4.44 & 5.84 & 1.40 & 4.81 & 1.03 \\
\hline 1965 & 4.68 & 5.85 & 1.17 & 5.02 & 0.83 \\
\hline 1966 & 5.39 & 6.58 & 1.19 & 6.18 & 0.40 \\
\hline 1967 & 6.19 & 6.54 & 0.35 & 6.93 & -0.39 \\
\hline 1968 & 6.45 & 7.23 & 0.78 & 7.23 & 0.00 \\
\hline 1969 & 7.72 & 8.25 & 0.53 & 8.65 & -0.40 \\
\hline 1970 & 7.64 & 8.38 & 0.74 & 9.12 & -0.74 \\
\hline 1971 & 7.25 & 7.77 & 0.52 & 8.38 & -0.61 \\
\hline 1972 & 7.08 & 7.66 & 0.58 & 7.93 & -0.27 \\
\hline 1973 & 7.68 & 8.49 & 0.81 & 8.48 & 0.01 \\
\hline 1974 & 8.89 & 9.37 & 0.48 & 10.55 & -1.18 \\
\hline 1975 & 8.79 & 9.01 & 0.22 & 10.35 & -1.34 \\
\hline 1976 & 7.98 & 9.10 & 1.12 & 9.12 & -0.02 \\
\hline 1977 & 8.19 & 9.09 & 0.90 & 8.99 & 0.10 \\
\hline 1978 & 9.16 & 10.02 & 0.86 & 9.94 & 0.08 \\
\hline 1979 & 10.74 & 11.64 & 0.90 & 12.06 & -0.42 \\
\hline 1980 & 13.21 & 13.26 & 0.05 & 15.14 & -1.88 \\
\hline
\end{tabular}

Source: Federal Reserve Bulletin, various issues.

a. Average rate in December.

b. The difference between the Federal Home Loan Bank Board effective rate and Moody's corporate Aaa rate.

c. The difference between the Federal Home Loan Bank Board effective rate and Moody's corporate Baa rate.

required to obtain the same restrictive effect because major credit programs automatically expand to protect their target sectors.

\section{FUTURES MARKETS IN FINANCIAL INSTRUMENTS}

Futures markets in financial instruments first appeared in October 1975 when the Chicago Board of Trade opened a facility for trading collateral depository receipts for Government National Mortgage Association (GNMA) securities. Subsequently markets have been introduced for Treasury bills, notes, and bonds; GNMA certificates; and commercial paper. In mid-January 1981, the Wall Street Journal reported that the volume of open contracts in Treasury bills, Treasury bonds, and GNMA certificates was close to $\$ 80$ billion. 
Superficially, financial futures markets appear to be a very modest extension of investment opportunities that are already available in securities markets through forward transactions. It has always been possible to make transactions that imply a specific forward interest rate by assuming a long-term and short-term position in government securities. The contribution made by the establishment of futures markets is that bets about interest rates on selected deliverable assets can be made more inexpensively than through forward transactions.

Viewed from another perspective, futures markets allow the making of bets about some interest rate to be decoupled from taking positions in assets and thereby tying up capital. This decoupling is useful to investors because securities have multiple attributes and are not solely used to place bets about interest rates. For example, commercial banks hold securities to satisfy collateral requirements against government deposits and to meet reserve requirements in the cases of some nonmember banks. Corporations hold securities in part so that they will have collateral for use in reverse repurchase agreements when short-term cash requirements arise. Individuals, until recently, have used futures markets and U.S. government securities to transfer taxable income across tax years.

The introduction of futures contracts also reduced the costs of individuals desiring to hedge against fluctuations in interest rates. This hedging function is socially useful even when futures markets are inaccurate in "discovering" future spot rates because risks are reduced for individuals who have imperfectly synchronized cash flows.

The obvious major reason for establishing a market in financial futures was the extraordinary volatility of interest rates that occurred in 1973 and 1974. Corporations and dealers needed to be able to hedge cheaply. Futures markets in commodities had been successful in providing opportunities to hedge and were easily imitated. As time passed, the number of financial instruments for which futures contracts were available expanded. Each additional market afforded new opportunities to bet about interest rates, but the marginal contribution of an additional market must have declined. Those who hedge can use futures markets for one instrument to ensure their position in another (cross-hedging). The gain from a new futures market is only the additional risk reduction or speculation that can be accomplished after all available opportunities to cross-hedge or speculate have been exploited.

Because of the short existence of financial futures markets, little re- 
liable information is available about how they are affecting the economy. Nevertheless, it seems likely that futures markets facilitate wealth holding and improve the allocation of investment flows by providing hedging opportunities that diminish risk exposure. They are not unambiguously expansionary, however, because they may attract speculators from highrisk, high-return investment projects. They pose problems for examiners of financial institutions because a speculative position could jeopardize an institution's solvency. Commercial banks do not appear to be especially active in the markets, but some conspicuous failures of thrift institutions have occurred because of speculative positions in GNMA futures. ${ }^{16}$

Futures markets are also likely to affect the effectiveness of monetary policy, since a firm contemplating an investment project can use the futures market to hedge against policy-induced fluctuations in interest rates. For example, if interest rates rise in response to a restrictive policy, the hedged firm has the option of carrying out the project at the lower interest rate that is implicit in its futures position. In imperfectly competitive capital markets, it is likely that hedging will lead to higher rates of investment at any interest rate. Higher interest rates will be required for monetary authorities to achieve a given restrictive effect. Discretionary policy shocks will fall heavily upon individuals who have not had the ability or foresight to hedge.

\section{SUMMARY}

These seven innovations do not exhaust the set of changes in financial markets, but in my view they are its most important elements. Collectively they opened new flows in and improved the efficiency of both money markets and capital markets by allowing savers and investors to have a greater opportunity to lend and borrow at a rate close to the real rate of interest. The innovations reduced distortions that arose from interest rate ceilings, reserve requirements, and other regulations.

The innovations came in two waves, 1966-69 and 1973-75; another may have commenced in 1980. It is clear that the tightening noose of regulation $\mathrm{Q}$ ceilings led directly to bank holding companies, Eurobranches, and a brief flirtation with repurchase agreements, and indirectly

16. See Marcelle Arak and Christopher J. McCurdy, "Interest Rate Futures," Federal Reserve Bank of New York Quarterly Review, vol. 4 (Winter 1979-80), pp. 33-46. 
to the expansion of off-budget agencies. High interest rates in 1973 and 1974 permanently established repurchase agreements, accelerated both Eurobranch expansion and the invasion of foreign banks, and fostered the development of money-market mutual funds. The growing volatility of interest rates surely encouraged the growth of financial instrument futures markets.

In the simple example in the first part of this paper, a high nominal loan interest rate led to an innovation. Since 1960 distortions in the structure of interest rates appear to have been the instigators. As in the example, the values of income multipliers of monetary policy instruments are likely to have been affected by innovations. Certificates of deposit, net purchased funds, Eurobranch deposits, and claims on money-market mutual funds are close substitutes for conventional monetary aggregates such as M1. With so many new close substitutes, these monetary aggregates should have become increasingly unreliable guides for the design of policy. The introduction of bank holding companies, financial instrument futures markets, and government credit programs have also changed financial markets in a variety of ways. They are harder to interpret in terms of monetary aggregates but likely to prove no less disruptive to the conduct of monetary policy.

\section{Monetary Policy When Innovation Is Possible}

A monetary authority has a large number of policy instruments at its disposal when attempting to achieve its goals. Thus regulations, the discount rate, and open market transactions can be directed toward targets for employment, investment, and the price level. Recent financial market innovations potentially affect all the linkages between policy instruments and such goals, but it is not feasible to examine how the innovations just described have altered the large number of existing linkages. Instead, the remaining pages examine how the relation between open market operations and nominal national income has been changed. To keep the story simple, it is assumed that an open market sale reduces both real income and the price deflator, but by amounts and timing that depend upon which innovations have occurred.

The discussion is presented in four parts, which consider the problem of recognizing when an innovation has occurred, how innovations have 
altered the role of interest rates as guides to policy, how innovations have changed the role of monetary aggregates as guides to policy and, finally, how deregulation and the increasing fragility of financial institutions are likely to modify policies. The discussion does not lead to a policy prescription that suggests authorities should peg some aggregate's growth rate or any particular interest rate. The structure of financial markets is changing and is too fluid for such inflexibility. However, it is argued that monetary authorities would be remiss if they allowed expected "real" interest rates to be perceived as negative.

The number of real interest rates in the market is the product of the number of price indexes and the number of nominal interest rates that are acknowledged to exist. In the following discussion it is assumed that the implicit price deflator is the appropriate price index. A strong case can be made for selecting the federal funds rate as the appropriate interest rate to use when calculating real interest rates. The federal funds rate is the price that banks and others are willing to pay for an additional dollar of outside, or fiat, money.

There are a number of serious technical problems with attempting to measure what the expected real federal funds rate is on any date. The fact that the federal funds rate is an overnight rate is not one of them, however, since anyone can construct an average of overnight rates for some arbitrary time interval. In this paper the average is taken over months or years.

\section{THE LAG IN RECOGNIZING INNOVATION}

For a number of reasons neither the Federal Reserve nor private observers were in a position to appreciate the importance of recent innovations when they occurred. First, reporting forms that banks and others submit are not designed to reveal innovation. New instruments appearing in bank portfolios are arbitrarily assigned to catchall categories on reporting form balance sheets such as other loans, other assets, other deposits and other borrowings, or are carried on the books of subsidiaries, which do not need to be reported.

Second, innovations grow from small seeds; in their early stages they were not very different from a number of other odd transactions in which banks engage. As they are adopted and imitated, innovations probably tend to alter observed relations between macroeconomic variables in the 
highly nonlinear manner suggested in the diagram below. The diffusion of an innovation through an industry might reasonably be approximated by a logistic function that applies to the slope of some behavioral relation. If so, marginal relations are likely to be especially misleading during the period of maximum diffusion. ${ }^{17}$

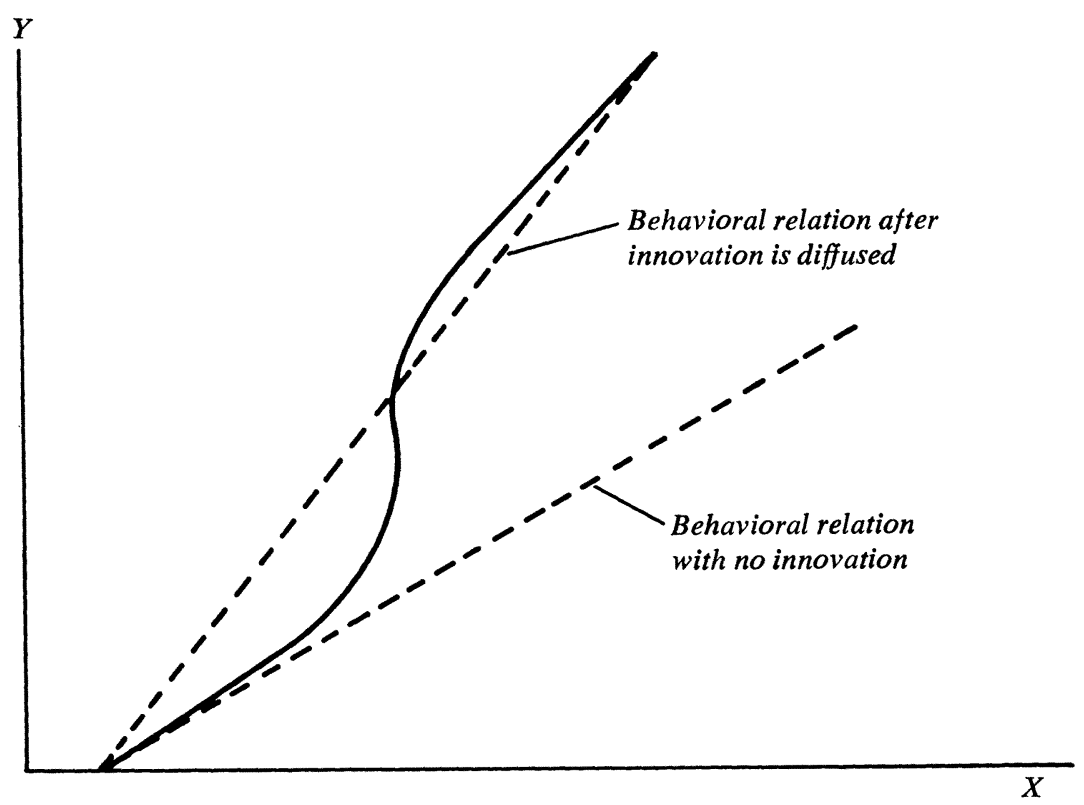

Third, innovating financial institutions are operating in new territory in which regulations are absent or at least unclear. Such institutions have no interest in drawing the attention of regulators and are not likely to volunteer information about changing practices. At any time, many financial "technologies" are being used in the economy; they all cannot be fully comprehended by everyone in the market or there would be no rewards for innovating. ${ }^{18}$ Secrecy, deception, and incomplete information

17. Something like this diffusion process appears to describe the breakdown in the demand for money that occurred in 1973. For a discussion, see Scott E. Hein, "Dynamic Forecasting and the Demand for Money," Federal Reserve Bank of St. Louis Review, vol. 62 (June-July 1980), pp. 13-23.

18. See Sanford J. Grossman and Joseph E. Stiglitz, "On the Impossibility of Informationally Efficient Markets," Stanford University Technical Report 259 (Stanford University, Institute for Mathematical Studies in the Social Sciences, 1978). 
are ever-present barriers to a monetary authority seeking to apply monetary controls to an economy in transition.

Fourth, the nature of discourse at the Federal Reserve makes it difficult to convince the Federal Open Market Committee in a timely fashion that an innovation has occurred. The standard requirement for an innovation to be taken seriously is empirical evidence of its occurrence. ${ }^{19}$ This is obviously a "Catch 22 " situation because no data about the innovation will have been collected. Thus monetary policy will be made on the assumption that nothing has happened. Once an innovation has been officially recognized to have occurred, it is necessary to devise a policy response that will attract near-unanimous support in the committee and will be defensible in the public domain. Many of the highly unorthodox policy actions taken by the Federal Reserve in the last eighteen months can only be understood in the light of trying to respond to these two constituencies.

\section{INNOVATION AND THE STRUCTURE OF INTEREST RATES}

Until the changes in operating procedure of October 1979, the federal funds rate was closely watched for clues about changes in monetary policy. Although there had been a continuing shift in emphasis by the Federal Reserve from controlling interest rates toward controlling monetary aggregates for about fifteen years, interest rates were convenient indicators because they were market statistics that could be accurately observed at short notice. The variability of the federal funds rate increased over time as the Federal Reserve shifted its emphasis increasingly from controlling interest rates toward controlling aggregates. The variability of short-term interest rates since October 1979 is without precedent in the postwar period.

All short-term interest rates reported in table 5 exhibited rising trends and increasing variability about these trends; they also moved distinctively relative to one another as innovations were adopted.

For example, a comparison of the interest rates on Treasury bills and on federal funds suggests that repurchase agreements were an important vehicle for avoiding restrictive monetary policy on several occasions in

19. See John T. Woolley, "The Federal Reserve and the Political Economy of Monetary Policy" (Ph.D. dissertation, University of Wisconsin-Madison, 1980). 


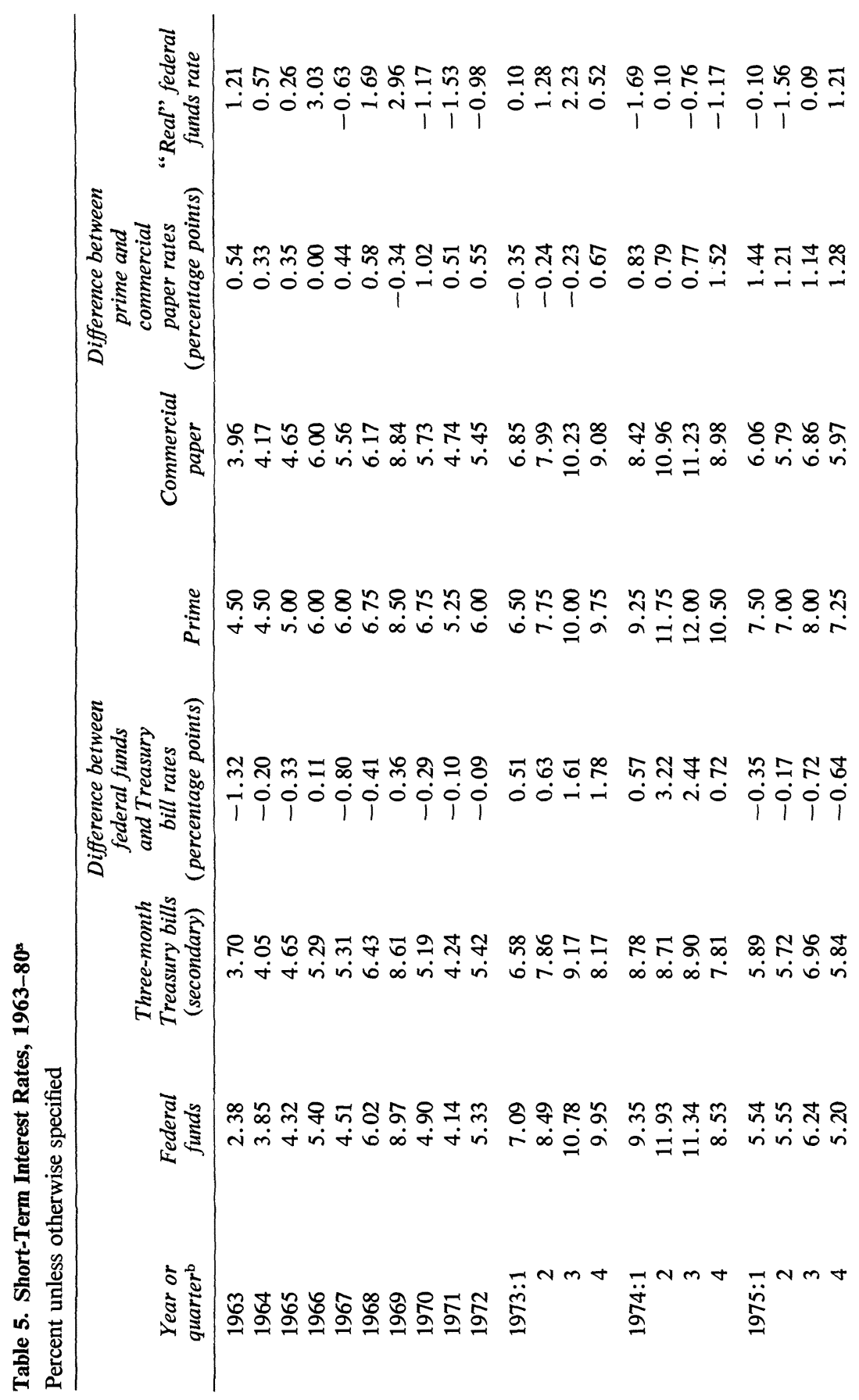




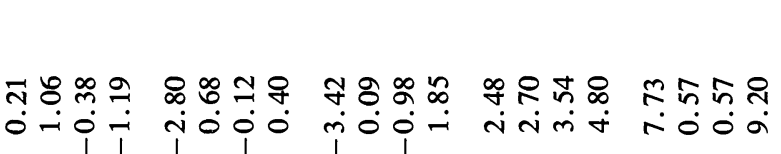

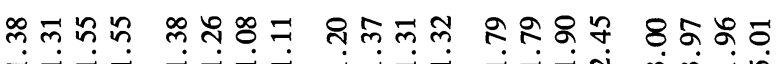

的落名

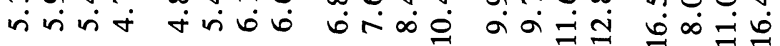

กำ ำกำ

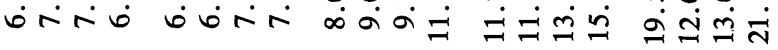

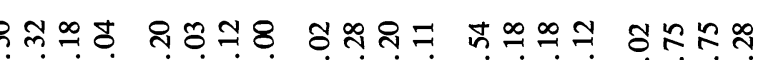
i

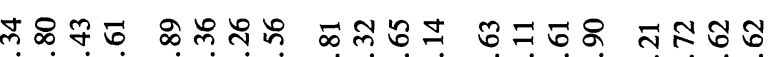

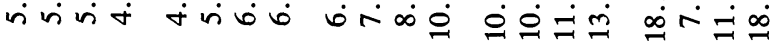

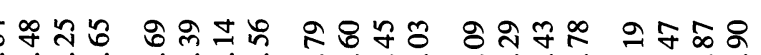

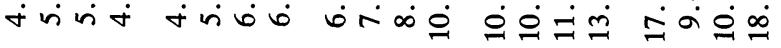

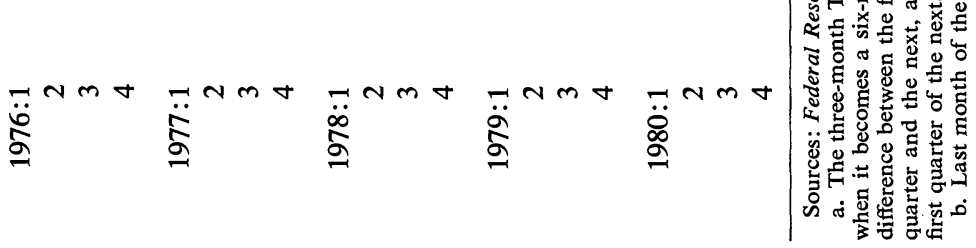


the recent past. The existence of repurchase agreements increases the demand for U.S. government and agency securities because these securities are required as collateral in such transactions. This collateral demand is likely to be of secondary importance when Federal Reserve policy is not restrictive. When monetary policy is restrictive, repurchase agreements ought to expand at the initiative of banks that seek to reduce their reserve requirements or corporations and state and local governments that seek to obtain the resulting high nominal interest rates on their transactions balances. A rough test of this conjecture can be performed by comparing the three-month Treasury bill rate and the federal funds rate in table 5. Using an arbitrary standard of a half percentage point difference between the two rates, it can be seen that the federal funds rate exceeded the Treasury bill rate by more than this amount in the eight quarters beginning with 1973:1, when demand functions for money began to go awry, and in 1980:2, when marginal reserve requirements were removed for net purchased funds. Although no other positive differences of this magnitude occur in the quarters shown, since 1964 there weve four other quarters when one existed: 1969:2, 1969:3, 1970:1, and 1971:3. The first three occurred during a period of very restrictive monetary policy when regulation $Q$ ceilings were universally binding and marginal reserve requirements were applied to Eurodollar borrowings and bankrelated commercial paper. The last quarter was the beginning of President Nixon's wage and price freeze, when the growth of M1 slowed down considerably for a period of almost six months.

I interpret this pattern to indicate that repurchase agreements were a vehicle for avoiding the consequences of restrictive monetary policy as measured by growth rates of aggregates such as M1. Repurchase agreements do not always perform in this role since other managed liabilities can also do the job. Their "safety valve" role can also be eliminated by imposing marginal reserve requirements like those of 1979:4 and 1980:1.

The changing relation between the prime loan interest rate at commercial banks and the commercial paper rate shown in table 5 reflects the effect of new sources of funds to business. In only three quarters between 1963 and 1974 did the prime loan rate exceed the commercial paper rate by as much as 0.75 percentage point (not shown in the table). Since the third quarter of 1974 the gap has never been lower than 1 point; since the fourth quarter of 1978 it has not been lower than 1.75 percent- 
age points. An interpretation is that growing access to the Eurodollar, repurchase agreement, and commercial paper markets by large multinational corporations is steadily reducing their dependence upon commercial banks for loans. The prime loan interest rate has increasingly become a rate that applies to firms that lack access to such markets, have correspondingly weaker bargaining power in loan negotiations, and are more likely to default. With few exceptions, the commercial paper rate has stayed remarkably close to the federal funds rate, which is the shadow price of outside money in the economy.

Finally, consider the real federal funds rate, constructed with the rate of change of the GNP deflator. End-of-year data between 1963 and 1972 indicate that the real federal funds rate was positive on average, but it was negative 40 percent of the time and in each of the three years leading up to the price explosion of 1973. One does not need to be a monetarist to claim that monetary policy was expansive in the early years of the last decade. ${ }^{20}$ The quarterly data show the real federal funds rate fluctuated between being positive and negative until 1978:4, when it turned positive (often strongly so) through the end of 1980. During the 1973-78 period the real rate was positive in thirteen of twenty-four quarters, but its mean value was negative. On Wicksellian terms, again monetary policy was not restrictive in this period.

An interpretation of these events is that by increasingly focusing on monetary aggregates, the Federal Reserve lost touch with the economy. During the years when innovations were being widely adopted, a given monetary aggregate's growth rate was associated with a lower than usual nominal interest rate and, therefore, a real interest rate that was lower than usual. As is shown below, financial innovations were permitting the measured income velocity of money to rise rapidly. Quantities that theoretically should have been included in definitions of money-such as overseas Eurodollar balances of corporations, repurchase agreements, and a variety of increasingly checkable consumer assets-were ignored and not measured.

20. On an annual basis, in each year between 1959 and 1970 an average of daily federal funds rates exceeded the inflation rate as measured by the GNP implicit price deflator by one percentage point or more. The real federal funds rate was negative for the years 1955 through 1958 and intermittently from 1971 through 1977. It was not happenstance that inflation was troubling in both periods. See the Economic Report of the President, January 1981, pp. 239, 308. 


\section{INNOVATION AND MONETARY AGGREGATES}

\section{AS GUIDES TO POLICY}

At a fundamental level, innovations in the past fifteen years have been particularly disruptive for the conduct of monetary policy because its strategy has been misconceived. While innovations have caused behavioral relationships to change, they would have been much less damaging if policymakers had not been trying to control ill-defined monetary aggregates. To explain why, it is useful to start with a few propositions concerning financial markets.

First, banks and other financial intermediaries survive and prosper by establishing long-term relationships with customers who are both borrowers and lenders. The objective of these institutions is to maximize the present value of these relationships, which may on occasion (but obviously not always) mean lending at an interest rate that is below the cost of funds. They must try to provide for their customers' needs at all times or risk losing them to rivals, in the United States or abroad. Banks are to be sharply distinguished from brokers who survive on brokerage fees, commissions, and the difference between bid prices and asked prices. Brokers prosper essentially from trading volume and turnover.

Second, attempts to restrict the liabilities of financial intermediaries by a monetary authority are extremely threatening to the future profitability of their customer relationships. Unexpected curtailments when loan demand is high will provoke intense innovative efforts by intermediaries to find substitutes for whatever is being restricted. Some of these efforts will be successful, and close substitutes for some liabilities will emerge. Credit requirements of good customers will be satisfied.

Third, from a narrow transactions-demand perspective, published monetary aggregates are inappropriate for conducting monetary policy. It is not necessary to reproduce the familiar, finite alphanumeric sequence of aggregate definitions or the discussion of their 1980 revisions to recognize the problems that arise from having multiple definitions. ${ }^{21}$ A less frequently discussed but no less important defect of monetary aggregates is the fact that they are only measured at the close of a business

21. See Thomas D. Simpson, "The Redefined Monetary Aggregates," Federal Reserve Bulletin, vol. 66 (February 1980), pp. 97-114. 
day when no transactions are occurring. Outside money is the sum of deposits at reserve banks and currency outstanding at that time. During a business day the volume of "immediately available funds" consists of this quantity plus a substantial quantity of additional funds that banks are allowed to regard as collected. Immediately available funds during a business day exceed the officially measured money base; the difference can roughly be approximated by the volume of overnight net purchased funds, perhaps 50 percent of member bank reserves in $1978 . .^{22}$ Immediately available funds are the transactions balances used by banks and their customers to conduct business. They are not proportional to the overnight level of outside money that the Federal Reserve controls. Banks and their customers can increase the ratio of immediately available funds to reserves by increasing the volume of funds that banks acquire through repurchase agreements.

Fourth, once the possibility of innovations and unobservable transactions balances is admitted, there is no basis for presuming that any particular positive nominal or real rate of interest will result when any particular monetary aggregate (including the monetary base) is required to grow at some fixed rate. If real interest rates are generally perceived by investors to be negative, the incentive to borrow is unbounded, except for the presence of risk aversion, and financial institutions will face great net demands for funds. Traditionally it has been assumed that institutions would adjust to this condition by raising interest rates to discourage borrowing. However, it seems they also respond in part by devising new financial arrangements that permit burgeoning loan demands to be profitably accommodated.

In light of these facts, the strategy for monetary policy must be oriented toward reducing credit-demand pressures that banks and other intermediaries face, rather than presuming that they will passively translate quantitative restrictions on their liabilities into higher loan interest rates. If the public understood that the Federal Reserve would always require that the expected real federal funds rate be positive, inflationary expectations would abate as would the current frenzy about the inflationary portent of recent growth rates in one or more monetary aggregates. Loan customers of intermediaries would weigh new borrowing decisions care-

22. For an extended discussion, see Hester, "Effects of Eurodollars and Domestic Money Market Innovations." 
fully and not simply lurch at the prospect of a quick gain from borrowing at a negative real interest rate.

This strategy acknowledges that there are limits to what monetary policy can achieve. Attempts to stimulate the economy with negative real rates of interest are likely to precipitate inflationary expectations and a new round of innovations. Attempts to stem inflation quickly with very high real interest rates may also breed innovations such as money-market mutual funds. Persistent high real interest rates can dampen capital formation. There will continue to be a need for discretion in setting the nominal federal funds rate in relation to expectations about inflation; monetary policy will only be as sound as the people and information that guide it. Avoiding a negative expected real interest rate for any extended period is only a necessary condition for controlling inflation; it is hardly a formula for conducting policy.

In sharp contrast to this strategy, the announced policy in recent years has been to set growth rates as objectives for certain aggregates and largely to ignore interest rates. This policy has not succeeded because innovations invalidated the justification for any particular growth target. Table 6 provides some evidence in support of this interpretation; it reports annual percentage growth rates for the principal monetary aggregates and their associated income velocities, using both the old and new definitions of the aggregates. Although varying growth rates in the aggregates have sometimes been blamed for poor economic performance, as the means data at the bottom of the table show, the annual changes in velocities have been more variable than the annual changes in the aggregates themselves.

Narrowly defined money velocities (velocities for M1 and M1B) grew especially fast in 1961 and 1962 when the competition for savings and time deposits was escalating, in 1965 and 1966 when interest rates rose in response to monetary policy initiatives and the Vietnam War escalation, in 1973 when net purchased funds surged, and in the 1975-79 period as the innovations were increasingly being assimilated. ${ }^{23}$ The longer-period growth rates, the five-year averages in the middle section of the table, indicate all the aggregates grew successively faster in each of the first three intervals shown, while in the fourth interval the growth

23. The M2 velocities are not more reliable. As the means data in table 6 reveal, annual M2 velocity growth rates are 20 percent and 35 percent more volatile, based on old and new data, respectively, than the M1 and M1B velocity growth rates. 
Table 6. Annual Growth Rates of Monetary Aggregates and Associated Income Velocities, 1960-79

Percent

\begin{tabular}{|c|c|c|c|c|c|c|c|c|}
\hline \multirow[b]{2}{*}{$\begin{array}{l}\text { Year or } \\
\text { period }\end{array}$} & \multicolumn{4}{|c|}{ Aggregates } & \multicolumn{4}{|c|}{ Income velocities } \\
\hline & $\begin{array}{l}\text { Old } \\
\text { MI }\end{array}$ & $\begin{array}{l}\text { Old } \\
\text { M2 }\end{array}$ & $\begin{array}{l}\text { New } \\
\text { MIB }\end{array}$ & $\begin{array}{l}\text { New } \\
\text { M2 }\end{array}$ & $\begin{array}{l}\text { Old } \\
\text { M1 }\end{array}$ & $\begin{array}{l}\text { Old } \\
\text { M2 }\end{array}$ & $\begin{array}{l}\text { New } \\
M 1 B\end{array}$ & $\begin{array}{l}\text { New } \\
\text { M2 }\end{array}$ \\
\hline \multicolumn{9}{|c|}{ Annual data } \\
\hline 1960 & 0.4 & 2.6 & 0.6 & 4.6 & 1.8 & -0.3 & 1.7 & -2.3 \\
\hline 1961 & 2.8 & 5.4 & 2.8 & 7.1 & 4.2 & 1.7 & 4.3 & 0.0 \\
\hline 1962 & 1.4 & 5.9 & 1.8 & 8.0 & 4.4 & 0.0 & 4.0 & -2.0 \\
\hline 1963 & 4.0 & 7.0 & 4.0 & 8.6 & 2.6 & -0.3 & 2.6 & -1.8 \\
\hline 1964 & 4.5 & 6.7 & 4.4 & 7.9 & 1.3 & -0.8 & 1.4 & -2.0 \\
\hline 1965 & 4.3 & 8.6 & 4.4 & 8.0 & 5.8 & 1.7 & 5.8 & 2.2 \\
\hline 1966 & 2.9 & 6.0 & 2.7 & 4.9 & 5.1 & 2.0 & 5.3 & 3.1 \\
\hline 1967 & 6.4 & 9.9 & 6.3 & 9.3 & -0.3 & -3.4 & -0.2 & -2.9 \\
\hline 1968 & 7.6 & 9.0 & 7.4 & 8.0 & 1.6 & 0.3 & 1.7 & 1.2 \\
\hline 1969 & 3.9 & 3.2 & 3.8 & 4.2 & 2.5 & 3.2 & 2.6 & 2.3 \\
\hline 1970 & 4.8 & 7.2 & 4.8 & 5.8 & -0.3 & -2.6 & -0.3 & -1.2 \\
\hline 1971 & 6.6 & 11.3 & 6.6 & 13.5 & 2.8 & -1.6 & 2.7 & -3.5 \\
\hline 1972 & 8.4 & 11.2 & 8.5 & 12.9 & 3.1 & 0.5 & 3.0 & -1.0 \\
\hline 1973 & 6.2 & 8.8 & 5.8 & 7.3 & 4.6 & 2.1 & 5.1 & 3.5 \\
\hline 1974 & 5.1 & 7.7 & 4.7 & 6.0 & 2.0 & -0.5 & 2.4 & 1.1 \\
\hline 1975 & 4.6 & 8.4 & 4.9 & 12.3 & 5.2 & 1.5 & 4.9 & -2.0 \\
\hline 1976 & 5.8 & 10.9 & 6.0 & 13.7 & 3.9 & -0.9 & 3.7 & -3.3 \\
\hline 1977 & 7.9 & 9.8 & 8.1 & 11.5 & 4.0 & 2.2 & 3.9 & 0.7 \\
\hline 1978 & 7.2 & 8.7 & 8.2 & 8.4 & 5.8 & 4.3 & 4.8 & 4.6 \\
\hline 1979 & 5.5 & 8.3 & 8.0 & 8.8 & 4.2 & 1.4 & 1.8 & 1.0 \\
\hline \multicolumn{9}{|c|}{ Five-year averages } \\
\hline $1960-64$ & 2.6 & 5.5 & 2.7 & 7.2 & 2.9 & 0.1 & 2.8 & -1.6 \\
\hline $1965-69$ & 5.0 & 7.3 & 4.9 & 6.9 & 2.9 & 0.8 & 3.0 & 1.2 \\
\hline $1970-74$ & 6.2 & 9.2 & 6.1 & 9.1 & 2.4 & -0.4 & 2.6 & -0.2 \\
\hline $1975-79$ & 6.2 & 9.2 & 7.0 & 10.9 & 4.6 & 1.7 & 3.8 & 0.2 \\
\hline \multicolumn{9}{|c|}{$\begin{array}{c}\text { Means of absolute values of } \\
\text { annual first differences }\end{array}$} \\
\hline $1960-79$ & 1.6 & 2.0 & 1.4 & 2.5 & 2.0 & 2.4 & 2.0 & 2.7 \\
\hline
\end{tabular}

Source: Federal Reserve Bulletin, vol. 66 (February 1980), pp. 112-13.

rates increased for the two new aggregate measures, but not for the old. Velocity growth rates peaked in the fourth for all measures except new M2, which includes many of the innovations of that period such as overnight Caribbean branch deposits, overnight repurchase agreements, and money-market mutual fund shares.

Policymakers could observe only the old aggregates until last year. 
It is easy to see how monetary policy may have become inadvertently too expansionary if the Federal Reserve was assuming that velocities were on their historic trends. Indeed, the real federal funds rate was unusually low between 1973 and 1978, at the time when velocities first began to accelerate. There is no reason to believe that the new monetary aggregates are going to be any more reliable in the future.

Events since the new aggregates policy was announced on October 6, 1979 , also testify to the problems confronting an aggregates approach. While the monetary base has grown at a fairly steady rate-primarily because of steady increases in currency holdings by the public-nominal interest rates, real interest rates, M1A, and M1B have fluctuated greatly in patterns that are reminiscent of those in 1973 and 1974. These fluctuations have been accompanied by a plethora of marginal reserve requirements, discount rate surcharges, emergency credit controls, unenforceable suasions, and opinions that can be found in the sections on announcements and legal developments of the Federal Reserve Bulletin, which are rapidly becoming its main features.

To illustrate, in October 1979 the Federal Reserve imposed marginal reserve requirements on federal funds purchases from nonmember banks, on funds acquired through repurchase agreements, and on net Eurodollar borrowings. In March 1980, using its powers under the Credit Control Act of 1969, the Federal Reserve imposed additional marginal reserve requirements on money-market mutual funds, on sales finance debt, and on credit card debt, much of which is financed in the commercial paper market. There is no clear connection between these actions and the M1A and M1B aggregates that were first defined in the February $1980 \mathrm{Federal}$ Reserve Bulletin. After the sharp collapse in the economy during the second quarter of 1980 , these marginal reserve requirements were abandoned. The new aggregates policy was allowed to operate without such supplements for the first time in the third quarter, when M1B grew at about twice its target rate.

\section{COMPETITION AND CONTROL}

Since the days of the Commission on Money and Credit it has been clear that changes in regulations and law are necessary to cope with new 
activities that are being undertaken by financial intermediaries. Congress has passed several important bills in recent years in an attempt to establish a suitable legal framework within which money and capital markets could efficiently function-the International Banking Act, the Financial Institutions Regulatory and Interest Rate Control Act of 1978 and, most important, the Depository Institutions Deregulation and Monetary Control Act of 1980. Partly in response to these legislative initiatives and partly on its own, the Federal Reserve has issued a large number of important rulings and opinions in the past few years.

A common theme of many of these laws, regulations, and opinions is encouragement of competition and elimination of artificial legal barriers such as differences in reserve requirements for similar deposits, interest rate ceilings, ability to branch, lending powers, and access to government services. The result of their elimination will be the disappearance of many monopolistic quasi-rents that had been haphazardly sprinkled through the financial system. If this process is allowed to run its course, the number of independent U.S. financial institutions can be expected to shrink considerably, and the nature of financial assets can be expected to change. The existing system has not fully assimilated the innovations that have been discussed above, and competition is a dynamic process that surely will be innovative.

A suggestion of what may be in store can be gleaned from the recent experience with money-market mutual funds. These funds attracted depositors at commercial banks and thrift institutions that were being heavily penalized by arbitrary and low interest-rate ceilings. The very existence of the money-market funds encouraged banks and thrift institutions to offer money-market certificates, NOW (negotiable orders of withdrawal) accounts, and several higher interest-rate time accounts. Although it is arguable that depository institutions would have offered these accounts in any event because of rising inflation and slow growth of their deposits, the expansion of money-market funds has certainly increased the pressure for such changes since 1977. The growth of these funds undoubtedly encouraged Congress to begin to eliminate interestrate ceilings in the Depository Institutions Deregulation and Monetary Control Act of 1980.

The services of money-market funds are similar to those of brokers; they accept very short-term liabilities and invest in very short-term assets. 
Because the funds have approximately matched the maturities of their assets and liabilities and have made no interest-rate commitments to their creditors, in periods of fluctuating interest rates they have a comparative advantage relative to institutions that attempt to provide services through fixed interest-rate commitments.

Commercial banks and thrift institutions are adapting by altering the mix of services they provide. Increasingly, all types of loans are being offered only on a "floating rate" basis. Some thrift institutions will only make very short maturity mortgage loans and thus are reducing the package of services they offer. Some have learned to hedge their positions in financial-instrument futures markets. Others are increasingly behaving as if they were mortgage bankers. They use mortgage pools to place fixedand variable-rate mortgages with the Federal National Mortgage Association and investors with long-term liabilities such as insurance companies and pension funds. The result of all these changes will be a much more efficient capital market in which the risk of inflation and fluctuations in the interest rate will be far more equitably shared between debtors and creditors. Money-market funds have played a major role in hastening these reforms.

Increasing competition also promises to modify the implementation of monetary policy. Recently the federal government and its financial regulatory agencies have felt compelled temporarily to support or bail out weak large institutions such as the Franklin National Bank, the city of New York, the First Pennsylvania Bank, and a number of endangered thrift institutions. Each of these decisions may be defensible on grounds of equity and efficiency, but each also softened the bite of monetary policy. Monetary policy works by discouraging individuals and firms from spending or expanding by making interest rates high and by depriving potential borrowers of their access to money and capital markets. The threat that credit may become too expensive or may be denied loses its force if firms can count on being bailed out.

Ratios of equity to debt and profit margins at large bank holding companies appear to be declining as a result of growing international competition. Failures and high leverage are as much a part of competition as death and high blood pressure are a part of life. Competition is likely to increase the fragility of the financial system and limit the set of policy moves that the Federal Reserve can undertake. There is no reason to think that the Federal Reserve would persist in aiming for some macro 
target if it became clear that large banks were imperiled. Limits on competition are probably a prerequisite for strong monetary policy.

\section{Conclusion}

The financial system will be in transition for most of the current decade. Monetary policy will have a major role to play in stabilizing and guiding the U.S. economy through this transition. This paper suggests several important guidelines for conducting policy during this period. First, nominal interest rates must be kept high enough to ensure that the public perceives real interest rates to be positive. Negative real interest rates have the potential to destabilize. Second, attention must be directed to the financial soundness of institutions in order to prevent sizable failures as the process of consolidation proceeds. Bank examinations will need to be strengthened, and some limits on competition are inevitable. Third, it will be necessary to collect more information about immediately available funds and about offshore banking activities that create close substitutes for outside money. It may be necessary to impede the transfers of funds domestically or outside the United States with wire transfer fees or other devices to retard growth in the volume of overnight Eurodollars and repurchase agreements. Fourth, greater coordination of federal credit programs and monetary policy will be necessary. Finally, the Federal Reserve should renounce target growth rates for any monetary aggregate. The one clear lesson from recent history is that financial institutions innovate whenever customer relationships are jeopardized by slow monetary growth.

\section{AP P ENDIX}

\section{The Design of Optimal Monetary Policy in the Presence of Changing Parameters}

THIS APPENDIX is a highly stylized illustration of how innovations alter policymaking in the context of a linear-difference equation system. Con- 
sider the conventional linear-difference equation system,

$$
B Y_{t}=A X_{t}+C Y_{t-1}+D U_{t}+E_{t},
$$

where $Y_{t}$ is a vector of contemporaneous endogenous variables; $X_{t}$ is a known vector of contemporaneous and lagged exogenous variables; $U_{t}$ is a vector of policy instruments available to some hypothetical monetary authority; $E_{t}$ is a vector of random variables with finite variances; $B$ is a known $m \times m$ matrix having rank $m$; and $A, C$, and $D$ are known $m \times n$, $m \times m$, and $m \times p$ matrices, respectively. Innovations cause the parameters in A-1 to be time-varying, resulting in

$$
B_{t} Y_{t}=A_{t} X_{t}+C_{t} Y_{t-1}+D_{t} U_{t}+E_{t} .
$$

It is well known that a linear difference equation system of any order can be expressed as a first-order state variable system such as A-1 above. ${ }^{24}$ If the monetary authority does not know values for $X_{t}, Y_{t-1}$, and $E_{t}$, that authority will not be able to achieve its target values, and the system is not perfectly controllable. A sufficient set of conditions for perfect control of a model such as A-1 over a finite time interval is that values of all elements in these vectors be known to the monetary authority and that there exist a subset of the elements in $U_{t}$ that is of order $m$ whose corresponding partition in $D$ has rank $m$.

If the monetary authority has a loss function that is quadratic, then the certainty equivalence principle implies that optimal policy instrument settings for model A-1 are linear functions of $X_{t}, Y_{t-1}$, and the authority's targets. ${ }^{25}$ If this system of linear equations is solved once over some planning period, $t=1, \ldots, T$, the resulting sequence of instrument settings constitutes open-loop control. If new information about the state of the system becomes available during the planning period and the linear system is repeatedly solved to incorporate this information, the resulting sequence of vectors constitutes open-loop control with feedback. Policy instrument settings that are generated using open loop with feedback are equivalent to those that emerge from an alternative dynamic programming or closed-loop formulation. ${ }^{26}$ The equivalence between the two

24. See Gregory C. Chow, Analysis and Control of Dynamic Economic Systems (John Wiley, 1975), pp. 152-56.

25. See H. Theil, Optimal Decision Rules for Government and Industry (Amsterdam: North-Holland, 1964), pp. 32-52.

26. See Alfred L. Norman, "On the Relationship Between Linear Feedback Control and First Period Certainty Equivalence," International Economic Review, vol. 15 (February 1974), pp. 209-15. 
approaches breaks down if either the model is nonlinear or if the loss function is not quadratic; it also breaks down if the coefficients in A-1 are random. ${ }^{27}$

To analyze the effects of innovations, it is necessary to make assumptions about the nature of parameter time dependence in expression A-2. I consider three specifications of parameter change: first, randomly changing - the output from some stationary stochastic process, second, exogenously changing-predictably changing in proportion to some exogenous variable (possibly just time), and third, endogenously changing-predictably changing in proportion to some endogenous variable. The placement of the changing parameters in matrices of expression A-2 is also important. In the subsequent discussion the possibility of a parameter change in each of the four matrices is briefly considered. Throughout this discussion it is assumed that $B$ is always full rank and that the number of policy instruments is always less than the number of target variables appearing with nonzero weights in the policymaker's loss function, which for convenience is assumed to be quadratic and time invariant relative to some arbitrary target path.

\section{Random Coefficients}

In the case of random coefficients, the interpretation of technical progress is that change is occurring at some basic level in the economy and appears as shocks to parameters in a model whose signs and magnitudes are not observed. For expositional convenience it is assumed that a single representative parameter in each of the matrices consists of a stationary expected value and a random component with zero expected value and finite variance. ${ }^{28}$ The random variable is assumed to be independent of other variables appearing in A-2. If the parameter occurs in the $A$ matrix, the problem is not substantially different from that of controlling with no parameter uncertainty. The error term in the affected equation can be

27. See Robert S. Holbrook and E. Philip Howrey, "A Comparison of the Chow and Theil Optimization Procedures in the Presence of Parameter Uncertainty," International Economic Review, vol. 19 (October 1978), pp. 749-59.

28. This expository assumption is very strong and not plausible in general unless the final form equation of the structural model is a first-order difference equation. In realistic control problems, a given parameter will appear in several equations once the model has been expressed in state variable form. 
thought of as the sum of two random variables and, therefore, targets will be more difficult to achieve in probability. If the random parameter occurs in the $D$ matrix, the problem is similar to one considered by Brainard..$^{29}$ His argument suggests that it will be optimal to have the absolute value of the associated policy instrument smaller than it is in the case of parameter certainty. If the parameter occurs in the $B$ matrix, reducedform parameters will all have unobserved shocks that are typically not independent of one another. In this case, one cannot conclude that any instrument should be used less vigorously than in the case of parameter certainty.

Finally, if the random coefficient occurs in $C$, impact multipliers are not affected, but the model may at times be stable and at other times unstable. A virtue of optimal control in the linear-quadratic framework is that it heavily penalizes large deviations from target paths and thus stabilizes systems that would otherwise be unstable. The principle of continuity allows one, therefore, to infer that the nature of the optimal solution when an element of $C$ is random would be that some policy instruments would tend to respond to deviations of the element's corresponding endogenous variable from its nominal path more than would be the case with parameter certainty. ${ }^{30}$

When several or all parameters in the various matrices have random components, a variety of patterns of policy instrument responses are possible. It is important to note that in all the cases considered there continues to be an optimal control mandate for intervention with policy instruments when random coefficients exist, even when the random component values are unknowable after the fact. ${ }^{31}$ There is no ground for believing that technical progress that manifests itself in random coeffi-

29. See William C. Brainard, "Uncertainty and the Effectiveness of Policy," American Economic Review, vol. 57 (May 1967, Papers and Proceedings, 1966), pp. 411-25.

30. See Roger Craine, "Optimal Monetary Policy with Uncertainty," Journal of Economic Dynamics and Control, vol. 1 (February 1979), pp. 59-83.

31. The possibility that one can take advantage of recent data to draw inferences about random shocks through filtering techniques has been intensively investigated by Tinsley and others at the Federal Reserve in a series of path-breaking papers. See J. H. Kalchbrenner and P. A. Tinsley with J. Berry and B. Garrett, "On Filtering Auxiliary Information in Short-run Monetary Policy," in Karl Brunner and Allan H. Meltzer, eds., Optimal Policies, Control Theory, and Technology Exports, Carnegie-Rochester Conference Series on Public Policy, vol. 7 (Amsterdam: NorthHolland, 1977), pp. 39-91. 
cients reduces the optimal amount of response of policy instruments in general, although such progress surely increases the volatility of endogenous variables and is likely to increase differences between realized and target path values.

\section{Exogenously Changing Coefficients}

The motivation for considering exogenously changing parameters is that this formulation captures two recognizable forms of technical change: the fully anticipated introduction of a new exogenous variable in a structural equation of a model, and the fully anticipated drift in one or more parameters that often accompanies the diffusion of an innovation across firms in an industry. When the parameters in a model change exogenously and predictably, the possibility exists that control will not be impaired at all. With a linear model and quadratic loss function, policy instruments in open-loop control with feedback continue to be linear functions of target path values and predetermined variables. Open loop with feedback and closed-loop control solutions will be equivalent in this specification because the sequence of parameter changes is assumed to be fully perceived.

With one important exception, few general conclusions about control can be drawn in the case of exogenously changing parameters. Clearly policymakers must allow for the effects of a changing element in $A$ when making forecasts or setting controls. If the changing parameter occurs in $D$, the dosage of some policy instruments (usually all) will need to be adjusted, but the appealing notion that one should reduce the dose of some instrument if the absolute value of one of its associated parameters rises is not sound. Similarly, knowledge that a parameter in $B$ is changing does not yield much insight about controllability, except when $B$ approaches singularity.

An especially important case in financial markets is a parameter change in an element of $C$ because many innovations are in a form that reduces transactions costs and thus reduces inertia in markets. Lagged endogenous variables are prominent in the financial sectors of most large structural models such as the public version of the Federal Reserve Board's quarterly model. A change in $C$ does not concern impact multipliers but is important for analyzing the stability of an equilibrium. 
To appreciate this case, consider the example of a single-equation model,

$$
y_{t}=a+c y_{t-1}+d u_{t}+e_{t} \text {. }
$$

Technical progress that reduces inertia does not necessarily modify the equilibrium level of $y$. In this example it is assumed that an equilibrium level of $y$ exists and is not altered by a technical change. The technical change involves a proportional change in $c$ that is matched by offsetting proportional changes in $a$ and $d$. The long-run equilibrium level of $y$ for equation A-3 is

$$
y=\frac{a+d u}{1-c} .
$$

If $c$ falls by some fraction, $r$, these assumptions imply that the counterpart of A-3 after the change is

$$
y_{t}=(1-r) c y_{t-1}+\left(1+\frac{c r}{1-c}\right)\left(a+d u_{t}+e_{t}\right) .
$$

Equation A-5 implies that the system becomes less controllable because the variability of shock terms is amplified. An interpretation is that the lagged endogenous variable provides a valuable mitigation service for policymakers by averaging together a sequence of random shocks, thereby exploiting a variation of the law of large numbers. This averaging contribution is weaker when $r$ is positive. The relevance of this example to models such as A-2 depends upon the nature of $C$ in large models and the extent to which the assumptions of the example are satisfied.

\section{Endogenously Changing Coefficients and Rational Expectations}

An even less tractable problem for analysis is when parameters are predictably changing in proportion to some endogenous variable. In part this is because the values of endogenous variables are themselves stochastic, which implies that the case of endogenously changing coefficients is a hybrid of the cases of randomly and exogenously changing coefficients. Open-loop control with feedback and closed-loop control solutions are not equivalent in these circumstances. From another perspective, when parameters are proportional to endogenous variables, the model's representation in A-2 is seriously misleading. Under these conditions the model is nonlinear. 
Nevertheless, extreme values of endogenous variables such as interest rates do lead to innovations involving new operating methods or new instruments. A distinctive feature of these innovations is that they are irreversible; once they appear, changes such as negotiable certificates of deposit, Eurobranches, money-market mutual funds, and repurchase agreements persist, even after interest rates fall away from peaks. Such "ratchet innovations" are a major part of postwar changes in financial markets.

Ratchet innovations may permit optimal control techniques to be applied within limits. If interest rates do not cross a threshold that calls forth a new regime, a model in which the only endogenously changing coefficients are of the form of ratchet innovations is linear. In this conditional sense of no regime change, optimal control techniques involving both open loop with feedback and closed loop can be applied, and the solutions will be equivalent. It is an illusory victory; the techniques are only useful when they are not used forcefully!

There is a related large rational expectations literature that denies (or at least questions) the effectiveness of persistent discretionary policy; this literature appears to imply the existence of endogenously changing coefficients. ${ }^{32} \mathrm{I}$ interpret its authors to be claiming that individual decisionmakers will modify parameters in expression A-2 in ways that will nullify the effects of discretionary changes in the elements of $U_{t}$. Discussions of rational expectations tend to be incomplete because one rarely is informed about which decisionmakers change which parameters and about the rates of change of parameters. If parameters change slowly and in a predictable manner, persistent discretionary policies can be effective.

In the foregoing discussion it has been assumed that rational expectations arguments weaken but do not nullify the effects of persistent discretionary policies. The reasons for this assumption are my beliefs that individuals and firms are risk-averse, that capital markets are inherently incomplete, that bankruptcy losses are uninsurable risks, that the costs for processing and disseminating information are too high for anything approaching full disclosure to exist, and that fragmented information systems are likely to prevent the full realization of the basic rational expectations denial of the effectiveness of persistent discretionary policy.

32. For references, see Robert E. Lucas, Jr., "Methods and Problems in Business Cycle Theory," Journal of Money, Credit and Banking, vol. 12, pt. 2 (November $1980)$, pp. 696-715. 


\section{Comments and Discussion}

Andrew S. Carron: To say that U.S. credit markets are now undergoing unprecedented changes would be to speak the truth, but a truth with a certain familiarity. Financial institutions in the United States have been evolving rapidly, particularly during the past twenty years, and inducing new and unanticipated corporate structures and investment alternatives. Donald Hester explains what has motivated these innovations, what their effect has been, and why there should be concern about them. In doing so, he has provided a useful foundation for discussion of an appropriate policy response. Hester himself initiates that discussion in the last sections of his paper, but it is by no means resolved.

He postulates three forces that motivate financial innovation: rising and volatile interest rates, regulations and regulatory changes, and ambiguities in domains of surveillance by monetary and fiscal authorities. Firms and individuals make their investment decisions from the set of available alternatives until one or more of these forces compel financial institutions to innovate, and thereby to survive. The innovation, even when successful, is not adopted instantaneously and may elude detection for a considerable time. In these initial stages, the monetary authorities are still operating under their previous view of the world, and thus are relying on increasingly incomplete information. Putting the case more concretely, Hester shows that attempts to restrict the stock of "money" will ultimately fail because institutions can create usable substitutes more readily than controls can be extended to cover them.

Recent financial history, then, is a cycle of credit restraint fostering innovations, which subsequently lead to further restraint. Hester illustrates this pattern in his review of seven major innovations and the economic circumstances surroun ling their creation. 
The process generating financial innovations could be characterized somewhat differently, however, and by doing so the debate on formulating a policy response can be sharpened. If one assumes that financial markets are initially in equilibrium, innovation comes about as a result of some change in the supply or demand schedule. Interest rate movements, the first of the forces Hester notes, constitute such a change, but the existence of regulations or gaps in regulatory surveillance does not. These latter forces are more appropriately viewed as fixed constraints.

There are price (interest rate) and quantity (reserves) controls. The existing regulatory constraints bind when exogenous factors (inflation) shift the market-clearing point out of the permissible range. Then institutions are motivated to incur the costs of innovation so that the market can clear within the existing constraints and loopholes. New regulations may follow, and in that way be considered a force for innovation, but to view such change as the motivating force would be to obscure cause and effect. Interest rate levels and swings, and the underlying supplies and demands for funds they represent, are the initiating forces. The regulatory response can then be analyzed in terms of Hester's model, in which the policy authorities either do not know all the instruments that are available or else for legal reasons cannot use them.

The effort to restrict monetary aggregates will be successful only to the extent that financial markets are segmented because there are too many substitutes for money that cannot be controlled. Policy thus focuses on instruments and quantities that can be affected and on the maintenance of artificial barriers among market segments. Deposit interest-rate ceilings and reserve requirements affect only parts of the capital markets. Restrictions on branching and the composition of assets, minimum balance requirements, and the tax treatment of thrift institutions are impediments to the flow of capital between sectors. Innovations thus may arise either to evade restrictions in a given sector (negotiable certificates of deposit, repurchase agreements, bank holding companies, Eurobranching, moneymarket mutual funds) or to lower barriers between sectors (federal credit programs, futures markets).

This distinction is important. The desire to reduce market segmentation may proceed even in the absence of monetary restraint. Hester does not make this point explicitly, but it does appear in his data. This may be seen in his discussion of federal credit programs. The secular narrowing of the "mortgage premium" in table 4 was virtually complete by 1968 , the year 
given as the starting point for major federal intervention in the mortgage market. In fact, although not shown in table 3 , federal credit agencies played a major role in supplying funds to the housing and agriculture sectors as early as 1957.

Such efforts to facilitate the flow of capital among sectors, which may derive from demographic shifts or other demand or supply changes unrelated to the control of monetary aggregates, are consistent with Hester's model. They result from a desire to equalize interest rates across sectors, whether those rates are high or low. These innovations improve allocative efficiency. True, they blunt the impact of monetary policy, but that is because the federal credit programs move the market closer to efficient operation. In the paper these are seen as politically motivated attempts to subsidize housing and agriculture. Some of the programs do advance credit on terms more favorable than actuarially sound. But most-Veterans Administration guarantees, Federal Housing Administration insurance, and Federal National Mortgage Association purchases, for example - are more appropriately evaluated as measures that remove impediments to the flow of capital between sectors. In any case, one cannot argue that the quantity of credit advanced under federal auspices is indicative of the level of subsidization (the attempt to evade controls). A plausible case can be made that the privatization of the sponsored credit agencies after 1968 reduced the subsidy component and focused the emphasis on capital market efficiency. Regulatory policy that increases market segmentation as an adjunct to monetary restraint thus has effects that go beyond the general suppression of economic activity.

Hester's conclusions may be generally viewed as favoring innovations, particularly insofar as they improve efficiency. Few would disagree with that point. Moreover, the rewards to innovation are so great and the regulatory structure so limited that the trend will continue. Indeed, at this very time, a number of significant innovations have been unveiled: the retail repurchase agreement, NOW accounts on foreign branches, the possibility of interstate branching by thrift institutions, and new types of adjustable-rate mortgages.

The level and volatility of interest rates are thus seen as the major factors inducing innovation. Hester's consideration of interest rate prescriptions is therefore on the mark. Given the prospect of continuing change in U.S. financial markets, his policy recommendations seem unequal to the task of restraining the growth of the (meaningful) monetary aggre- 
gates while permitting improvements in allocative and transaction efficiency. If we are to rely on monetary restraint, forestalling innovation may be necessary. The preceding argues for concentrating regulatory restrictions on innovations that serve principally to evade monetary policy by removing funds from federal control rather than on those that shift credit among sectors. Particularly disturbing, therefore, is Hester's observation that large banks can hold the Federal Reserve hostage by taking big risks, knowing that the viability of the banks is more important than any particular monetary target. By extension, then, no policy of restricting bank lending (whether through regulation or monetary policy) can work. Perhaps that is the essence of the message. A valid conclusion may be that restrictive monetary policy will never be maintained for very long either because it does work (too well) or because it does not (as a result of innovation). We would do well to look elsewhere for weapons against inflation.

Stephen M. Goldfeld: Donald Hester has given us an interesting and thoughtful paper on a variety of issues in monetary policy. Hester emphasizes the importance of financial innovations that have changed monetary practices and, indeed, most of the paper is devoted to explaining and documenting the key innovations. These inevitably affect the proper course of monetary policy, especially when one recognizes that innovations may be partially induced by monetary policy. Hester ably illustrates the difficulties created by ongoing innovations and makes several recommendations for adapting policy. Two of these stand out-namely that the Federal Reserve should renounce having target growth rates for monetary aggregates and, instead, should adopt a discretionary policy focusing on real interest rates.

The existence and importance of financial innovations is undeniable and, I wholeheartedly agree, casts serious doubt on the meaning of various monetary aggregates and therefore on the wisdom of a mechanistic monetary target approach to policy. I also concur with the notion that real interest rates have a potentially important role to play in monetary policy. Nevertheless, I remain a bit uneasy with the strong tone of the policy conclusions. While the paper does give a "pep" talk to the Federal Reserve and even points them in the right direction, it falls short of presenting a fully articulated policy alternative. Furthermore, it seems to gloss over some realistic problems in the conduct of policy. Although 
my comments are largely devoted to the elaboration of these points, I first want to dispose of a few thoughts on innovations per se.

Much has been written in recent years about innovation. There is often a bit of schizophrenia in these discussions about whether or not innovation is good. On the one hand, innovations tend to contribute to a more efficient capital market; on the other, they tend to complicate the task of monetary policy and reduce its effectiveness. This conflict is evident in Hester's paper as it was in the recent discussion by Albert Wojnilower in $B P E A, 2: 1980$. Thus Hester recognizes the virtues of innovations, but he suggests the need to limit competition and to impede various types of flows of funds. There seems to be no clear way, however, to evaluate how one strikes a sensible balance in this regard, and Hester therefore does not discuss how much friction is really desirable.

Desirability aside, it also is important to understand why innovation comes about. Hester conveys a sense of this by his detailed analyses of a number of important innovations. Although these analyses have a loose framework regarding what stimulates innovations, no general theory of innovations is provided. This is hardly a criticism of the paper, but the absence of such theory does suggest that policymakers are likely to experience difficulties in sorting out possible innovations ex ante. Hester argues that, even ex post, policymakers are likely to experience difficulty in recognizing that innovations have taken place. This same line of argument leads him to eschew any sort of formal econometric analysis of the consequences of innovations in favor of presenting bits and pieces of suggestive evidence. Here I think he was being overly pessimistic, but nevertheless his basic point is well taken-that is, lags in the process of recognizing the full consequences of innovations are a potential serious impediment to the conduct of monetary policy.

Hester gives rather low marks to the performance of monetary policy over the past decade. He observes that by at least one simple measure (discussed further below) the real rate of interest was inappropriately negative from 1970 to 1972 and importantly contributed to the dismal inflation that followed. Over the years from 1973 to 1978 - a period in which Hester characterizes the Federal Reserve as increasing its focus on monetary aggregates and losing touch with the economy-the average real rate of interest by his measure was essentially zero. Innovations play a role in Hester's explanation of why low real interest rates emerged. 
High nominal rates of interest stimulated a variety of changes in cashmanagement techniques, which served to increase monetary velocity and shift the relation between money and interest rates. And banks, scrambling to satisfy the loan demand of their valued customers, found innovative ways to circumvent the restrictive policies of the Federal Reserve.

Based on this experience, Hester concludes that monetary policy should focus on real interest rates, while aiming to achieve an adequately positive real rate, and the Federal Reserve should abandon its policy of targeting on monetary aggregates. Indeed, Hester states that developments since October 1979 testify to the "problem confronting an aggregates approach." Although I am sympathetic to the intent of these recommendations, more needs to be said about both real interest rates and monetary aggregates.

While the notion of avoiding negative real rates of interest seems clearly desirable, more precision is necessary if real rates are to guide policy. Hester does suggest that the Federal Reserve must avoid real rates that are too low or too high because both extremes will stimulate innovations that confound policy, but he is relatively silent on the Goldilocks question of how to decide which real rate is "just right." He does not say much, for example, about the period after mid-1978 when his measures show a rather positive average real rate but yet, at least by implication, monetary policy was still inadequate. Is the rate in this period too high or not high enough? Is it too variable or is it inappropriate in some other way? More generally, how should real rates be varied to cope with shocks of various types? Being able to answer such questions would increase my confidence that, as Hester suggests, we can leave the choice of the appropriate real rate to discretionary monetary policy.

A related issue in this regard is the proper measurement of the real rate of interest. There is the question of which nominal rate should form the basis for the calculation, and this involves, among other things, the choice of a horizon. There is also the issue of the corresponding inflation rate and how expected inflation is to be estimated. Another complication concerns the treatment of taxes-should we be dealing with an after-tax real rate? Hester is well aware of these issues and recommends use of the real federal funds rate. I did not, however, find the justification for this choice to be fully convincing. The empirical importance of various definitional aspects is illustrated in the recent work of Frederic Mishkin which, 
however, does confirm the impression that real rates have been negative in the 1970s. ${ }^{1}$ (Mishkin's results, incidentally, suggest a negative real rate through the end of 1979 , whereas Hester's measure turns positive in late 1978.)

One of the arguments for conducting policy in terms of real interest rates is that the meaning of the monetary aggregates has grown increasingly slippery, thus muddying the relation between such aggregates and more fundamental economic variables. While this raises considerable doubts about an aggregates policy, there can be a corresponding degree of slipperiness between real interest rates and other economic variables. For example, Hester raises the possibility that the interest rate futures market can alter the relation between business fixed investment and interest rates. Similarly, Hester acknowledges that high interest rates could breed innovation and thereby change the impact of interest rates on economic activity. Changes of this sort, emphasized in Wojnilower's recent paper (BPEA, 2:1980), are worth noting. For one, the growth of variablerate financial instruments means that a given interest rate will not be locked in and hence may not inhibit expenditures by as much as it would in the past. Similar effects may result from the reduced importance of interest rate ceilings (usury or otherwise), which in the past might have served to restrict economic activity by causing a credit crunch. These developments, in conjunction with new mortgage rate instruments including creative self-finance, have served to render housing activity somewhat more immune to given swings in interest rates. As these examples should make clear, the relation between real rates of interest and other fundamental economic targets is also subject to change over time.

By raising these various issues, I do not mean to negate Hester's main point that real interest rates are a proper and indeed necessary concern of monetary policy. Nevertheless, a discretionary monetary policy based on real interest rates is hardly straightforward, and a realistic evaluation of the likely success of such a policy is not a simple matter. The natural question is what is the alternative? At the moment, the only live option seems to be a policy based on monetary aggregates. Hester would have the Federal Reserve repudiate this approach. Although I can imagine the Federal Reserve leaning in this direction, as a matter of political and economic reality such action strikes me as a little impractical. At the very

1. Frederic Mishkin, "The Real Interest Rate; An Empirical Investigation," Working Paper 622 (National Bureau of Economic Research, January 1981). 
least, this ignores the considerable interest of both Congress and the current administration in the pursuit of monetary targets.

There is also the issue of the credibility of the Federal Reserve. By its actions, both on October 6, 1979, and subsequently, it reinforced the achievement of monetary targets as a basis for its report card. As much as the Federal Reserve may now find this criterion too confining, and there is evidence that this is the case, it cannot blithely abandon the monetary aggregates. At the very least, this would raise a number of questions about the response of private expectations to such a move.

For better or worse, it appears to me to be likely that monetary targets will be around for some time to come. The danger that this presents for the economy is, however, not the one to which Hester devotes primary attention-a real rate that was too low. Rather, it is the mindless pursuit of steadily reducing monetary targets that could well yield a real rate that is too high and result in periods of economic overkill.

On balance then, I would certainly support the general thrust of Hester's recommendations. The remaining problems seem to be twofold: how can we reduce the emphasis on mechanical targeting, and can we address the various issues with a practical policy on the real rate that will bolster its attractiveness and retain the element of accountability that some observers find desirable in an aggregates policy?

\section{General Discussion}

Many participants agreed with Hester's thesis that financial innovation alters the relation between the monetary aggregates and the rest of the economy. Albert Wojnilower argued that policy should try to regulate the monetary system so as to discourage financial innovation and thus maintain a more predictable environment for the conduct of monetary policy. If policymakers allow the system to change, they will be forced to attempt stabilization through ad hoc policies with little chance of success. He did not believe that an emphasis on real interest rates could provide stabilization in the face of innovations because interest rates were less decisive than availability in achieving control. George von Furstenberg and James Tobin argued against excessive reliance on the real federal funds rate for stabilization because it was only one of many real rates in the economic system, because it was relatively distant 
from decisionmaking by firms and households, and because its relation to other, more relevant rates was endogenous and might itself be affected by innovation. Tobin contended that policy should rely on all available information, including financial aggregates and interest rates, and attempt to judge how innovations are altering the meaning of this information for the conduct of policy. He also suggested the use of a money wage index in converting nominal interest rates to real rates. A wage index is a better estimate than a price index of the long-run rate of inflation, and a real interest rate in terms of labor may be more relevant for investment decisions. Alan Blinder added that, if the government issued indexed bonds, it would facilitate the use of real interest rates as a guide to policy.

Robert Hall agreed with Hester that stabilizing monetary aggregates was an inappropriate rule for the conduct of policy. However, Hall disagreed that maintaining positive real interest rates would necessarily slow the inflation rate. To accomplish that, he endorsed slowing nominal GNP as the appropriate target for monetary policy, using the real interest rate as an intermediate variable for achieving that target. Alan Greenspan replied that nominal GNP is only known with a considerable lag, making it a difficult measure to use in adjusting an interest rates policy. $\mathrm{He}$ and others found more merit in maintaining targets for monetary aggregates. Greenspan noted that, despite financial innovations, the velocity of M2 has remained quite stable during the past two decades. Robert Gordon believed that the evidence on innovations did not change the verdict that, to slow the growth of nominal GNP, policy should slow the growth of monetary aggregates. Charles Schultze reasoned that with the present chronic inflation rate well above the growth targets for the aggregates, policy today would be judged restrictive for any plausible estimate of the distortion that innovations were making to the relation between the aggregates and GNP. Thus under virtually all reasonable forecasts the current targets for the monetary aggregates will provide the monetary authorities with a very useful political defense against attacks on their tight money policies, even though innovations will render unpredictable the exact degree of the resulting tightness. William Fellner suggested subjecting new financial instruments to the same reserve requirements as their competitors, not just as a device to discourage innovation, but also to maintain the original relation between reserves and nominal GNP, thus facilitating the use of monetary aggregate targets.

The panel then turned to a discussion of the causes of innovation. Benjamin Friedman stressed that they were often induced by a high op- 
portunity cost in the existing system rather than by the low opportunity cost of outside money that Hester had emphasized. Wojnilower suggested that interest rate spreads were as important as levels in encouraging innovation. Christopher Sims reasoned that regulation of the banking industry inherently creates an incentive to invent substitutes for banking services while avoiding regulations, and that changes in the particular method of conducting policy are thus unlikely to remove the incentive to innovate.

Several participants discussed the desirability of innovations and of policies to control them. Hall and Greenspan advocated allowing all types of innovations because they improved economic efficiency and reasoned that the Federal Reserve served no useful purpose in interfering with that process. David Fand thought it important to distinguish between innovations that genuinely improve efficiency from those that simply represent evasions of regulation. Sims pointed out there were good reasons for regulating the banking system, such as deposit insurance and the use of monetary policy for stabilization. Unless legal boundaries were maintained between the banking system and the intermediaries, monetary policy would become increasingly ineffectual. Thus the authorities had to regulate. Tobin suggested that it was easy to exaggerate the significance of disintermediation. If $\mathrm{A}$ lends to $\mathrm{B}$ at market interest rates, it is not of great macroeconomic consequence whether it occurs directly or through a bank. Important dimensions of innovations are the degrees to which they economize bank reserves and the extent to which they substitute market-rate assets for controlled-rate assets. Wojnilower advised classifying them by the degree to which the innovation extended the role of the Federal Reserve as a lender of last resort.

Charles Holt suggested that econometric methods could be developed to model the relations needed for stabilization in the presence of innovation. He recommended regression techniques that allow for coefficients that drift over time by giving more weight to relatively recent observations, logistic functions that allow for the diffusion of innovations, and Bayesian techniques that permit the incorporation of qualitative effects into estimation.

Commenting on Hester's discussion of the developing market in interest rate futures, Sims observed that investment decisions would still depend on the opportunity cost of making them. Thus these decisions would remain sensitive to current interest rates even if firms covered their borrowing needs ahead of time in the futures market. 